NBER WORKING PAPER SERIES

\title{
THE EFFECTS OF STATE MEDICAID POLICIES ON THE DYNAMIC SAVINGS PATTERNS OF THE ELDERLY
}

\author{
Lara Gardner \\ Donna Gilleskie \\ Working Paper 12208 \\ http://www.nber.org/papers/w12208 \\ NATIONAL BUREAU OF ECONOMIC RESEARCH \\ 1050 Massachusetts Avenue \\ Cambridge, MA 02138 \\ April 2006
}

The views expressed herein are those of the author(s) and do not necessarily reflect the views of the National Bureau of Economic Research.

(C)2006 by Lara Gardner and Donna Gilleskie. All rights reserved. Short sections of text, not to exceed two paragraphs, may be quoted without explicit permission provided that full credit, including $\odot$ notice, is given to the source. 
The Effects of State Medicaid Policies on the Dynamic Savings Patterns of the Elderly Lara Gardner and Donna Gilleskie

NBER Working Paper No. 12208

April 2006

JEL No. I1, I3

\begin{abstract}
States have considerable flexibility in determining Medicaid policies such as financial eligibility criteria, subsidies for home- and community-based services, and reimbursements rates to skilled nursing facilities, among other things. An understanding of how differences in Medicaid programs across states and time affect the elderlys' demand for Medicaid coverage of long-term care is necessary for evaluating future changes in the Medicaid program structure. We use data from the 1993, 1995, 1998, and 2000 waves of the Asset and Health Dynamics of the Elderly and variation in state Medicaid policies over time to estimate our dynamic framework capturing the sequential asset and gift decisions that determine eligibility for Medicaid. We also model the long-term care decisions of married and single individuals conditional on endogenous insurance coverage and health transitions. To control for the impact of unobserved heterogeneity in all outcomes, the structural equations of the empirical model are estimated jointly, allowing for correlation in the error structure across equations and over time. In this paper we focus on the asset and gifting decisions of the elderly over time. We find that many of the Medicaid policy variables that differ across states have a significant but small effect on the savings decisions of the elderly, with single elderly individuals exhibiting more response than married elderly individuals.
\end{abstract}

\author{
Lara Gardner \\ Florida Atlantic University \\ The College of Business \\ Fleming West 137 \\ Boca Raton, FL 33431-0991 \\ lbryant@fau.edu \\ Donna Gilleskie \\ Department of Economics \\ University of North Carolina, Chapel Hill \\ CB \#3305, 6B Gardner Hall \\ Chapel Hill, NC 27599-3305 \\ and NBER \\ donna gilleskie@unc.edu
}




\section{Introduction}

At the beginning of the $21^{\text {st }}$ century an elderly person who anticipates the need for long-term care faces average annual costs of $\$ 35,000$ to $\$ 100,000$ to live in a skilled nursing facility, and between $\$ 7,500$ and $\$ 33,444$ to receive home- and community-based services. ${ }^{1}$ Long-term care (LTC) services are likely to be the largest catastrophic expenses facing the elderly because most LTC services are not covered by Medicare or private insurance. ${ }^{2}$ Elderly individuals and their families spent almost \$42 billion on LTC services in 2000 while Medicaid LTC expenses amounted to $\$ 44$ billion. Medicaid is available only to individuals with income and assets below state-specific limits, and in some states, to those with medical expenses that reduce wealth below a qualifying limit.

While Medicaid is available to many low-income elderly, it is increasingly becoming an option for the middle-class elderly due to the high costs of long-term care and increased longevity. Economic theory predicts that an asset-based, means-tested insurance program with a deductible equal to one's wealth creates strong incentives for elderly individuals who anticipate the need for expensive LTC to transfer their assets in order to become eligible for Medicaid (Hubbard, et al., 1994; Sloan, et al., 1996). Such a transfer also allows the elderly to protect their bequeathable wealth. Some eligible individuals, however, do not apply for Medicaid due to a lack of information and/or understanding of the Medicaid application process, or because of a stigma associated with receiving Medicaid payments. In fact, if an elderly person is welfare averse, she may accumulate wealth instead of transferring assets, perhaps by increasing savings and lowering consumption. By accumulating wealth she can pay for future medical expenses from

\footnotetext{
${ }^{1}$ These cost estimates are based on the MetLife Mature Market Institute Survey 2002 found at http://cgi.money.cnn.com/tools/elder_care/elder_care_cost_finder.html. Louisiana has the lowest and New York, the highest cost.

${ }^{2}$ Very few employer-provided health insurance plans cover long-term care. Although private LTC insurance policies exist, they are very expensive and held by few elderly individuals.
} 
private savings for a longer period of time and avoid dependence on Medicaid.

This paper investigates the influences of health and the variation in state Medicaid policies on the savings patterns, insurance coverage, and long-term care decisions of elderly persons who anticipate the need for long-term care. States have considerable flexibility in determining policies that affect the attractiveness of receiving Medicaid coverage for long-term care (Norton, 2000; U.S. General Accounting Office, 1990). Although states must adhere to federal guidelines when designing a Medicaid program, there are large variations in Medicaid policies across states.

Medicaid policies are explained in Section II. In Section III we develop a dynamic stochastic model that provides a framework for understanding the savings and insurance decisions and long-term care arrangements of elderly individuals with uncertain health paths. We hypothesize that the rules for eligibility, reimbursement to providers, supply restrictions and the generosity of home-care programs significantly influence savings behavior and the decision to enroll in Medicaid. Specific questions of interest include: 1) Do Medicaid policies have a clear impact on the savings patterns of elderly individuals? Are people spending down or saving when they perceive the need for care? 2) What are the effects of Medicaid policies on the probability of enrolling in Medicaid?

To answer these questions we estimate a dynamic empirical model, detailed in Section IV, that captures the simultaneity and endogeneity of decision making about insurance, long-term care, and asset allocations over time. The empirical model uses data from the 1993, 1995, 1998, and 2000 waves of the Assets and Health Dynamics of the Elderly. We also conduct simulations of behavior using the estimated parameters of the model to allow us to explore the effects of Medicaid policy changes on the choice variables. The data are described in Section V, and in Section VI the estimation and simulation results are analyzed. Section VII concludes. 


\section{Background}

In February 2006 President Bush signed the Deficit Reduction Act, which changed the asset transfer rules for Medicaid coverage of long-term care. The new rules reflect the Administration's strong belief that middle-class and wealthy seniors are transferring assets to relatives to impoverish themselves, and then qualifying for Medicaid to pick up their nursing home bills. Prior to the Act a person had to wait three years after transferring assets to become eligible for Medicaid. Now states can look for asset transfers over the prior five years, and the ineligibility period does not start until one applies for Medicaid. Also, whereas the primary home was not counted towards Medicaid eligibility, under the new law if you have more than $\$ 500,000$ in home equity, you cannot qualify for Medicaid coverage. And, if you are single and have Medicaid long-term care coverage, the government will supplant your children or other loved ones as the secondary beneficiary. The Bush administration expects to generate $\$ 100$ million in annual savings with these measures.

Policy-makers' beliefs that the elderly are transferring assets to qualify for Medicaid is reinforced by recent theoretical work that suggests that Medicaid nursing home coverage could have large negative effects on the personal savings of the elderly who anticipate the need of nursing home care (Hoerger, Picone, and Sloan, 1996; Hubbard, Skinner, and Zeldes, 1995; Norton, 1995). Studies have also found that there is little enforcement of restrictions on the transfer of assets, and, in fact, there exists a network of professionals to help the elderly successfully shield their assets from Medicaid (Moses, 1990; Sloan and Shayne, 1993).

However, there is little empirical evidence on the extent to which the elderly actually do transfer assets for Medicaid eligibility. The view that many elderly people become Medicaid recipients after staying in a nursing home is inconsistent with the empirical evidence that comparatively few persons switch to Medicaid after being admitted (Spence and Weiner, 1990; 
Liu, Doty, and Manton, 1990). Using data from two different samples of the elderly, Norton (1995) found the actual time of spend-down was much longer than a predicted time of spenddown absent of behavioral effects, indicating that the elderly try to avoid Medicaid eligibility.

Policy-makers are still debating proposals for altering the public financing of long-term care because of the high costs of LTC and the projected large growth in the number of elderly. Over the next three decades the number of elderly is projected to more than double, rising from 35 million in 2000 to more than 70 million in 2030 (Tilly, et al., 2001). This is likely to result in a significant increase in the demand for LTC despite recent declines in disability rates among the elderly. ${ }^{3}$ The aim of recent policy proposals is to help contain costs while still helping those in need of assistance. Traditionally, the strategies used by states to control Medicaid costs have been to tighten eligibility rules, lower payments to providers, limit supply of services, and eliminate coverage of services. Yet further reductions in eligibility, reimbursement, and service coverage could result in many elderly persons not receiving the care they need. An understanding of how changes in Medicaid rules will influence utilization and costs is therefore crucial to the effectiveness of proposals for changes in public financing of LTC. Awareness of how current differences in Medicaid programs across states affect the demand for and supply of LTC, via eligibility and take up of Medicaid, will lead to better predictions of the effects of future changes in the Medicaid program structure.

\section{A. Long-Term Care Coverage Options}

Unlike Medicare, which is a federally administered program, Medicaid is directed by each state under broad federal guidelines. States determine eligibility requirements, available services, reimbursement rates to providers, and restrictions on construction of nursing homes. Lack of Medicaid coverage can impose substantial financial burdens on low- to middle-income aged

\footnotetext{
${ }^{3}$ The Urban Institute predicts that the number of persons age 85 and older receiving home care services and
} institutional care will rise from 7.4 million in 2000 to 15 million in 2050 (Tilly, et al., 2001). 
persons because Medicare and most private supplemental insurance plans do not cover long-term care. Medicare covers up to a maximum of 100 days of care in a skilled nursing facility, and only for persons who have had a prior hospital stay that lasted at least three days. The high costs of obtaining private insurance for long-term care make it unavailable to most elderly, and there are often barriers to coverage such as limits due to preexisting conditions.

\section{B. Medicaid Benefits}

There are two mandatory benefits that must be covered by all states and two optional services. Nursing home care and home health care are the two mandatory benefits. ${ }^{4}$ Medicaid influences the demand for these types of care by establishing eligibility policies that determine the prices of care, and by limiting access to care. States also have the option of providing Medicaid coverage for home- and community-based services and/or personal care services. Financial eligibility requirements for Medicaid programs are discussed in Section III.

The home- and community-based services (HCBS) waiver program is the primary mechanism for providing Medicaid funded, community-based, long-term care services. In response to criticism of Medicaid's institutional bias, the program provides federally-matched funding and allows state to "waive" certain Medicaid statutory requirements so that they can expand HCBS and reduce the use of institutional care. Since the primary goal of the HCBS Waiver is to offer alternatives to institutionalization, HCBS may only be offered to persons who meet the institutional level-of-care criteria. ${ }^{5}$ This requirement was established in response to concerns that long-term care expenditures might increase if many individuals who would not otherwise use nursing home care would use HCBS. From 1992 to 1999, Medicaid expenditures on HCBS

\footnotetext{
${ }^{4}$ Federal regulations require that home health services include nursing services, home health aides, medical supplies, medical equipment, and appliances suitable for use in the home. States have the option of providing additional therapeutic services under home health, including physical therapy. An individual is not required to meet a state's nursing facility level-of-care criteria in order to receive home health benefits.

${ }^{5}$ Services covered under waiver programs usually include: case management, homemaker, home health aide, personal care, adult day health, habilitation, and respite care.
} 
Waivers for the aged and disable increased 270\% (based on HCBS data). ${ }^{6}$ In 2000 all states had at least one waiver program for the aged.

States also have a very high level of discretion to determine who will receive the other optional

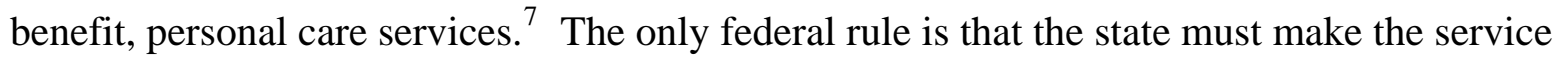
equally available to all recipients who satisfy the service criteria that have been set. In 2000, 27 states covered personal care services under their Medicaid state plans.

\section{The Dynamic Behavioral Model}

\section{A. Overview and Timing}

In the beginning of each period an elderly individual (age 65 or older) observes her health state and assets from the previous period. Given her Medicaid eligibility, an individual chooses either to be insured by Medicare health insurance only, to supplement it with private insurance with or without long-term care coverage, or to enroll in Medicaid. Health in the current period is then realized and the individual decides on her long-term care arrangement and asset allocations. The per-period decisions depend on endogenous previous decisions or realizations, observed exogenous characteristics, and relevant policy variables. Hence the framework captures the dynamic optimization behavior of individuals over time.

\section{B. The Per-Period Decisions}

All individuals are assumed to be covered by both Part A and Part B of Medicare. ${ }^{8}$ Because Medicare covers short stays in a nursing home following a hospital stay but does not provide residence in a nursing home and only covers limited home health care, an elderly individual may

\footnotetext{
${ }^{6}$ See http://www.hcbs.org/hcbs_data.htm

${ }^{7}$ Since the mid-1970s, states have had the option to offer personal care services under the Medicaid state plan. Personal care services may span provision of assistance not only with Activities of Daily Living (ADLs), but also with Instrumental Activities of Daily Living (IADLs), such as personal hygiene, light housework, laundry, meal preparation, transportation, grocery shopping, using the telephone, medication management, and money management.

${ }^{8}$ In fact, $95 \%$ of the sample in this analysis are enrolled in the optional Part B.
} 
choose to supplement this government-provided health insurance. Each individual has the option to hold no additional insurance $(i=0)$, to purchase private insurance that does not cover long-term care $(i=1)$, or to purchase private insurance that does cover long-term care $(i=2)$. Conditional on her assets, she may also be eligible for Medicaid ( $i=3)$, which does cover long-term care arrangements. (Medicaid eligibility is discussed in detail in sub-section F.) The individual's health insurance choice determines her financial out-of-pocket responsibility for subsequent medical care consumption. The indicator $d_{t}^{i}=1$ if insurance alternative $i$ is chosen in period $t$ and $d_{t}^{i}=0$, otherwise. Alternatives are mutually exclusive such that $\sum_{i=0}^{I\left(A_{-1}^{u}\right)} d_{t}^{i}=1, \quad \forall t=1, \ldots T$, where $I$ is the insurance choice set available to an individual in period $t$. This choice set depends on her unprotected assets entering the period, $A_{t-1}^{u}$, which determine Medicaid eligibility.

Having chosen health insurance, the individual then realizes her current health state. Conditional on her health insurance, health, and previous assets, she decides upon her long-term care arrangement and allocation of current period assets. The LTC options are no care $(k=0)$, informal home care $(k=1)$, formal home care $(k=2)$, or nursing home care $(k=3)$, where $d_{t}^{k}=1$ indicates that arrangement $k$ is chosen in period $t ; d_{t}^{k}=0$ otherwise. Alternatives are mutually exclusive such that $\sum_{i=0}^{3} d_{t}^{k}=1, \quad \forall t=1, \ldots T$.

An individual chooses the amount of her assets to hold in the form of "countable assets," which are used to determine if an individual meets the Medicaid asset limit. Although what is included in countable, or unprotected assets, $A_{t}^{u}$, varies slightly across states, in most cases it includes all wealth except the value of the primary home, transportation, and some life insurance.

An individual also chooses how much of her assets to give away as "gifts." This "gifts" 
decision, $A_{t}^{g}$, is modeled in order to capture attempts by the individual to transfer wealth to become eligible for Medicaid. The variable includes gifts given to friends and relatives, money given to charity, and home improvements. Thus, "gifts” are exempt from Medicaid eligibility, and cannot be liquidated by the individual for consumption expenditures. This framework allows previous assets and their return, $\left(1+r_{t}\right) A_{t-1}^{u}$, as well as other current period income, to be allocated in period $t$ between consumption $\left(C_{t}\right)$, savings $\left(A_{t}^{u}\right)$, and gifts $\left(A_{t}^{g}\right) .{ }^{9}$

\section{Uncertainty}

The per-period decisions depend on the history of the individual up to the current period. This history defines the state at which an individual enters a new period; that is, the information that she has at the beginning of the period. The endogenous state variables include health $h_{t-1}$, insurance status $d_{t-1}^{i}$, LTC arrangement $d_{t-1}^{k}$, and countable assets $A_{t-1}^{u}$ in the previous period. ${ }^{10}$ A vector of demographic characteristics that are assumed to be exogenous, $X_{t}$, including age, gender, race, ethnicity, education, marital status, and an indicator for a change in marital status from married to single, is also known at the beginning of the period. We also assume that the individual knows all prices, $P_{t}=\left(r_{t}, p_{t}^{i}, p_{t}^{m}, p_{t}^{n}, O_{t}\right)$, which are defined below. Individuals are

\footnotetext{
${ }^{9}$ Although a home is generally not counted towards Medicaid eligibility, the home is technically subject to transfer prohibitions; a person entering a nursing home is allowed to transfer his/her home only to a spouse, minor or disabled child, or in some circumstances, sibling or adult child. Previous research suggests that most elderly persons hold the majority of their savings in the form of housing (Venti and Wise, 1991). Housing assets are not used to determine Medicaid eligibility before Feb. 2006. Other types of savings that are protected from Medicaid include life insurance, burial plot, and car value up to some small amount. Of these protected assets, housing value comprises the largest proportion. For the purpose of this analysis, variations in housing value is taken as given. That is, the model does not explicitly allow for the individual's decision to sell (or buy) a home and housing wealth is not included in the measurement of assets. Previous research documents that persons 65 and over simply do not move very often (Venti and Wise 1989a, 1989b). In the AHEAD data, $75 \%$ of the sample own a home at the start of the survey (1993). Of these, less than 4\% (who are still alive in 2000) sold their homes.

${ }^{10}$ The length of time an individual has received a particular type of LTC could also influence the physical and emotional transaction costs involved in switching to a new long-term care arrangement. For example, the search costs of finding a provider of formal home care or institutional care, or the comfort established with an informal provider, may inhibit the search for formal and/or institutional care. Or, if an individual has received any type of care over a significant period of time she may develop a dependence on care and therefore be unwilling (or unable) to function without such help. Because the data set used for the empirical analysis does not provide this information prior to the initial survey, we do not formally include duration in a particular LTC arrangement as a state variable.
} 
also aware of Medicaid policies in their state, $Q_{t}^{s}$. The state vector entering period $t$ is denoted

$$
z_{t}=\left(h_{t-1}, d_{t-1}^{i}, d_{t-1}^{k}, A_{t-1}^{u}, X_{t} P_{t}, Q_{t}^{s}\right)
$$

Health evolves each period and is stochastic. The period $t$ health state is denoted $h_{t}$, taking on values 0 to $\mathrm{H}$, where increasing values indicate worsening health. For simplicity of exposition, let $h_{t}=0$ indicate good health, $h_{t}=1$ indicate bad health, and $h_{t}=2$ indicate death. Conditional on survival to period $t$, the probability of health state $h$ in period $t$ is

$$
\pi_{t}^{h}=p\left(h_{t}=h \mid h_{t-1,} d_{t-1}^{k}, d_{t}^{i}, X_{t}, \mu\right)
$$

and is modeled as a time-varying Markov probability of transitioning from one health state to another health state that depends on individual demographic factors and decisions made in the previous period. The probability of death at the end of period $t$ (i.e., of not surviving to period $t+1), \gamma_{t+1}$, is defined similarly as

$$
\gamma_{t+1}=p\left(h_{t+1}=2 \mid d_{t}^{i}, h_{t}, d_{t}^{k}, X_{t}\right) .
$$

The type of long-term care a person received in the previous period, $d_{t-1}^{k}$, may impact current period health. If an elderly individual needs help with bathing, walking, eating or other ADLs, she may hurt herself by not receiving the required care. For example, she may fall while trying to walk or trying to enter/exit a bathtub alone. A care provider can also help an elderly person to properly take medications, which would influence health. The dependence of the health probability on the insurance choice, $d_{t}^{i}$, is intended to capture the effect of other endogenous medical care inputs which are affected by insurance coverage.

There is also a random shock to health that is unobserved at the beginning of the period. The shock to health occurs after the insurance decision, so in each period $t$ the choice of insurance is based on expectations of health shocks in the period. After the health state has been observed, 
the LTC arrangement and assets decisions are made and the individual then updates expectations of future health shocks and observes transitions in the state variables. Conditional on these transitions and updated expectations, the individual repeats the decision process in the next period, if she survives.

\section{Per-Period Utility and Budget Constraint}

An individual derives utility directly from the choice of long-term care arrangement, gifts, and consumption, conditional on the insurance choice. Utility is a function of these observables and an error term that is health and choice specific: $U^{h}\left(C_{t}, d_{t}^{k}, A_{t}^{g}, X_{t}, \varepsilon_{t}^{h k g u}\right)$, where consumption $C_{t}$ is determined in the budget constraint below. She first chooses health insurance which potentially reduces income, or cash on hand, $Y_{t}^{c}$. That is,

$$
Y_{t}^{c}=Y_{t}+\left(1+r_{t}\right) A_{t-1}^{u}-p_{t}^{i}\left(d_{t}^{i}\right)
$$

where $Y_{t}$ is earned and non-earned income, $r_{t}$ is the interest rate, and $p_{t}^{i}\left(d_{t}^{i}\right)$ is the price (or premium) associated with insurance choice $i$. She then allocates this cash on hand to her chosen long-term care arrangement (whose prices depend on insurance status) and savings, gifts, and consumption. Her budget is also reduced by exogenous out-of-pocket medical expenses $\left(O_{t}\right)$ that are determined by health status and health insurance coverage. The budget constraint is

$$
Y_{t}^{c}=p_{t}^{m}\left(d_{t}^{i}\right) \times d_{t}^{k=2}+p_{t}^{n}\left(d_{t}^{i}\right) \times d_{t}^{k=3}+O_{t}\left(d_{t}^{i}, h_{t}\right)+A_{t}^{u}+A_{t}^{g}+C_{t}
$$

where $p_{t}^{m}$ and $p_{t}^{n}$ are the individual's costs of home care and nursing home care at time $t$, respectively. These prices are a function of the parameters of the insurance plan $i$. The gifts constraint is $A_{t}^{g} \geq 0$.

\section{E. The Optimization Problem}

To reiterate, an individual chooses insurance at the beginning of the period, based on health 
and other events in the previous period. Health in the current period is then realized and the individual makes the LTC choice and asset allocations. Utility is a function of these variables, consumption, and an error term that is specific to the health, long-term care arrangement, and asset decisions.

Conditional on the choice of health insurance and the health state realization, the objective of an individual is to choose the type of long-term care arrangement and asset allocation so as to maximize her expected present discounted value (EPDV) of lifetime utility, subject to her budget constraint. The value of choosing long-term care arrangement $k$ and asset allocation $u$ and $g$ in period $t$, conditional on health insurance $d_{t}^{i}$ and health in period $t, h_{t}$, is

$$
V^{k g u}\left(z_{t}, \varepsilon_{t}^{h k g u} \mid d_{t}^{i}, h_{t}\right)=U^{h}\left(C_{t}, d_{t}^{k}, A_{t}^{g}, X_{t}, \varepsilon_{t}^{h k g u}\right)+\beta\left[\gamma_{t+1} B\left(z_{t+1}\right)+\left(1-\gamma_{t+1}\right) W\left(z_{t+1}\right)\right], \forall t
$$

where $\beta$ is the discount factor and $\gamma_{t+1}$ is the probability of survival to period $t+1$. If the individual dies, she receives the value of death which may be a function of her assets, $B\left(z_{t}\right)$. This formulation allows for a bequest motive among the elderly. If she survives, her future value of lifetime utility, $W\left(z_{t}\right)$, captures the subsequent insurance decision, health transitions, and long-term care, gifts and assets decisions. More specifically, the maximal value of lifetime utility in period $t$, conditional on insurance and health, is

$$
V\left(z_{t} \mid d_{t}^{i}, h_{t}\right)=E_{t-1}\left[\max _{k g u} V^{k g u}\left(z_{t}, \varepsilon_{t}^{k g u} \mid d_{t}^{i}, h_{t}\right), \quad \forall k, g, u\right], \quad \forall t
$$

where $E[\cdot]$ is the expectations operator over the distribution of $\varepsilon_{t}^{k g u}$. The value of choosing health insurance option $i$ at the beginning of the period is

$$
W^{i}\left(z_{t}, \varepsilon_{t}^{i}\right)=U^{i}\left(h_{t-1}, \varepsilon_{t}^{i}\right)+\sum_{h=0}^{H} \pi_{t}^{h} V\left(z_{t} \mid d_{t}^{i}, h_{t}\right), \quad \forall t
$$

where $U^{i}($.$) represents preferences for insurance and \pi_{t}^{h}$ represents health transition probabilities. Finally, the maximal value of lifetime utility at the beginning of period $t$ is 


$$
W\left(z_{t}\right)=E_{t-1}\left[\max _{i} W^{i}\left(z_{t}, \varepsilon_{t}^{i}\right), \quad \forall i\right], \quad \forall t
$$

The insurance decision represented by $W\left(z_{t}\right)$ embeds the availability of Medicaid as an insurance option. The individual's choices in previous periods interact with the Medicaid policy variables to determine eligibility.

The effects of the Medicaid policy variables and other exogenous variables on the outcomes of interest are difficult to derive because they depend (importantly) on the history of the many (discrete and continuous) choices. In Section VI, we describe results from a series of simulations that predict an individual's per-period decisions under various Medicaid policy changes. By evaluating changes in the outcomes of interest under various Medicaid policy scenarios, we recover the unconditional impact of Medicaid policies on the outcomes of interest.

\section{F. Eligibility for Medicaid}

A person living in state $s$ must meet either the categorically needy or medically needy income and asset limits to be eligible for Medicaid. These state-determined asset limits may be different for the categorically needy and the medically needy programs. Also, the financial eligibility requirements for the mandatory services, nursing home and home care, are identical, but the financial eligibility requirements for the HCBS Waivers can be the same or different from the financial eligibility requirements for the mandatory services.

To be eligible for a state's categorically needy program, income must be below the income limit for the categorically needy, $\bar{Y}_{t, s}^{\text {cat }}$ (for state $s$ in time $t$ ) and assets must be below the state asset limit, $\bar{A}_{t, s}^{u, c a t}$. Therefore, eligibility for Medicaid in a state that does not have a medically needy program requires that $A_{t}^{u} \leq \bar{A}_{t, s}^{u, c a t}$ and $Y_{t} \leq \bar{Y}_{t, s}^{\text {cat }}$ in state $s$.

However, if an elderly person has income or assets that exceed the categorically needy limits, 
she may still qualify for Medicaid if the state has a medically needy program. ${ }^{11}$ Eligibility for Medicaid in a state that does have a medically needy program also requires that assets are below the program's asset limit, $A_{t}^{u} \leq \bar{A}_{t, s}^{u, m e d}$, but the income requirements are more complicated. A medically needy program allows the individual to deduct medical expenses from income to determine eligibility for Medicaid. Medical expenses are covered by Medicaid at time $t$ if $Y_{t}-\left[O_{t}(\cdot)+p_{t}^{m} d_{t}^{k=2}+p_{t}^{n} d_{t}^{k=3}\right] \leq \bar{Y}_{t, s}^{u, \text { med }}$, where $p_{t}^{m}, p_{t}^{n}, O_{t}$ are out-of-pocket medical expenses related to formal home care, nursing home care, and other medical expenses, respectively. If a state does not have a medically needy program, individuals with income above the categorically needy income threshold are ineligible for Medicaid even if they do not have enough income to pay the cost of long-term care. ${ }^{12}$

In addition to the financial eligibility requirements, to be eligible for HCBS elderly individuals must meet institutional level-of-care criteria. $^{13}$ This is a statutory requirement added by Congress in part to address concern about the cost of expanding HCBS: states must demonstrate that they are providing waiver services only to people who are eligible for institutional placement.

Although the financial eligibility requirements for HCBS Waivers are important in determining the use of HCBS, studies have suggested that Medicaid policies that most influence the demand for home care under HCBS waiver coverage are the number of persons a state covers under a waiver and the amount of income and assets a person or couple may retain while receiving

\footnotetext{
${ }^{11}$ Asset and income limits for both the categorically needy and the medically needy programs in each state are detailed in Appendix Table A1.

${ }^{12}$ States that do not have a medically needy program are required to allow elderly persons to establish a Miller Trust, which is designed for those whose income is over the income limit, but who do not receive enough monthly income to pay for nursing care costs. Although this is available, few elderly use this option (Taylor, Sloan, and Norton, 1999).

${ }^{13}$ Level-of-care criteria explicitly describe the type and level of functional limitations or needs an individual must have in order to be admitted to an institutional setting. These criteria usually include measures of need for assistance with Activities of Daily Living (dressing, eating, bathing, toileting, walking, in/out of bed) and for other services, including nursing and medically related services.
} 
HCBS coverage. In every state, once eligibility for HCBS Waivers is determined, the state then calculates how much income and assets the individual may retain based on the state's maximum limits. These 'maintenance needs allowances (MNAs)' vary significantly across states. States' MNAs are shown in the first column of Appendix Table A2.

\section{The Empirical Specification}

\section{A. Equation System}

An individual maximizes lifetime utility subject to the budget constraints and borrowing constraints. The individual's observed decisions are expected to be the ones that jointly provide the greatest EPDV of lifetime utility (equations 5 and 7 from Section III). From (7) and the assumption that $\varepsilon_{t}^{i}$ enters additively and has an Extreme Value distribution, $\bar{W}^{i}\left(z_{t}\right)$ is the deterministic component of the value function. That is, $\bar{W}^{i}\left(z_{t}\right)=W^{i}\left(z_{t}, \varepsilon_{t}^{i}\right)-\varepsilon_{t}^{i}$. These assumptions yield a multinomial logit probability of each insurance option where

$$
p\left(d_{t}^{i}=1\right)=\frac{e^{\bar{W}^{i}\left(z_{t}\right)}}{\sum_{i^{\prime}=0}^{3} e^{\bar{W}^{i}\left(z_{t}\right)}}
$$

$\bar{W}^{i}\left(z_{t}\right)$ can be approximated by an $n^{\text {th }}$ order Taylor series expansion of its argument $z_{t}$. In order to consider permanent and time-varying heterogeneity that may influence the insurance decision as well as other decisions and health transitions in the model, we decompose the error term $\varepsilon_{t}^{i}$ into three components. More specifically, $\varepsilon_{t}^{i}=\rho_{1 i} \mu+\omega_{1 i} v_{t}+u_{t}^{i}$ where $\mu$ and $v_{t}$ represent permanent and time-varying individual unobservables, respectively, and $\rho_{1 i}$ and $\omega_{1 i}$ are factor loadings on the heterogeneity terms. Also, $u_{t}^{i}$ is the remaining i.i.d. Extreme Value distributed error.

If people are modifying their behavior to satisfy eligibility criteria, as the model suggests, then 
ignoring the endogeneity of eligibility may bias results. Thus, it is more appropriate to model the decision to participate in Medicaid in each period only for persons who are eligible for Medicaid. ${ }^{14}$ All persons who choose not to enroll in Medicaid would choose among the other insurance options only. Thus, we estimate insurance probabilities for $i=0,1,2$ as in Equation (4), conditional on not enrolling in Medicaid. $\bar{W}^{i}\left(z_{t}\right)$ is approximated as

$$
\bar{W}^{i}\left(z_{t}\right) \approx \alpha_{0 i}+\alpha_{1 i} h_{t-1}+\alpha_{2 i} A_{t-1}^{u}+\alpha_{3 i} Q_{t}^{s}+\alpha_{4 i} X_{t}+\alpha_{5 i} E_{t}+\rho_{1 i} \mu+\omega_{1 i} v_{t}
$$

where $h_{t-1}$ and $A_{t-1}^{u}$ are endogenous lagged health and assets, $Q_{t}^{s}$ is a vector of Medicaid policy variables that influence the expected financial benefits of eligibility and access to care in state $s$, $X_{t}$ is a vector of demographic variables assumed to be exogenous: marital status, age, gender, race, education, an indicator for a change in marital status, and number of children, and $E_{t}$ is an indicator for Medicaid eligibility based on assets at the end of the current period. Unobserved permanent and time-varying individual heterogeneity is captured by $\mu$ and $v_{t}$. The probability of enrolling in Medicaid, estimated on all individuals due to data limitations on accurate measurement of eligibility, is

$$
p\left(d_{t}^{i=3}=1 \mid \mu, v_{t}\right)=\frac{\exp \left(\alpha_{03}+\alpha_{13} h_{t-1}+\alpha_{23} A_{t-1}^{u}+\alpha_{33} Q_{t}^{s}+\alpha_{43} X_{t}+\rho_{2} \mu+\omega_{2} v_{t}\right)}{1+\exp \left(\alpha_{03}+\alpha_{13} h_{t-1}+\alpha_{23} A_{t-1}^{u}+\alpha_{33} Q_{t}^{s}+\alpha_{43} X_{t}+\rho_{2} \mu+\omega_{2} v_{t}\right)}
$$

Unobserved heterogeneity is likely to influence insurance decisions as well as decisions regarding long-term care arrangement, gifts, and savings. Similarly, it may affect health transitions. For example, an individual who is highly risk averse will be more likely to buy long-

\footnotetext{
${ }^{14}$ Because of the two or three year lag between waves in the AHEAD data, basing eligibility for Medicaid on lagged asset levels is potentially incorrect. That is, some individuals spend down their assets between waves and hence become eligible during the two or three year gap. Individuals in the sample report receiving Medicaid coverage at time $t$, when asset levels in $t-1$ are above the Medicaid eligibility limit. Hence, we include all individuals in the equation capturing the Medicaid participation decision. Those who did not enroll in Medicaid face the other three insurance options. We include a dummy variable indicating Medicaid eligibility (according to lagged assets) in the multinomial insurance equation.
} 
term care insurance and to save more. Or an individual may have unobserved knowledge of her genetic disposition that influences her decisions. If someone anticipates failing health, she may also expect to be unable to manage her personal finances in the future, and to need significant long-term care. Thus she may give gifts to her children to acquire informal care and/or as a way of qualifying for Medicaid to cover long-term care expenses. Hence, health insurance probabilities are estimated jointly with health, survival and long-term care probabilities, and gift and asset levels.

Although health is described in the behavioral model as being dichotomous, the data provide enough information to model health as a continuous variable. The health variable used in this analysis is an index constructed from a raw score of the total difficulty with Activities of Daily Living (ADLs) and Instrumental Activities of Daily Living (IADLs): one point for a difficulty with an IADL and two points for a difficulty with an ADL. The raw score is converted to an index by taking the log of values created by the formula: $10 *$ (respondent's score)/(highest scorelowest score). ${ }^{15}$ Thus, conditional on being alive in period $t$, an individual's health is defined as

$$
h_{t}=\beta_{0}+\beta_{1} h_{t-1}+\beta_{2} d_{t-1}^{i}+\beta_{3} d_{t-1}^{k}+\beta_{4} X_{t}+\rho_{3} \mu+\omega_{3} v_{t}+\varepsilon_{t}^{h}
$$

where $\varepsilon_{t}^{h}$ is an independent and identically distributed error term. The insurance choice and long-term care arrangement in the previous period are endogenous explanatory variables. The probability of not surviving to period $t+1$ is

$$
p\left(h_{t+1}=H \mid \mu, v_{t}\right)=\frac{\exp \left(\delta_{0}+\delta_{1} h_{t}+\delta_{2} d_{t}^{i}+\delta_{3} d_{t}^{k}+\delta_{0} X_{t}+\rho_{4} \mu+\omega_{4} v_{t}\right)}{1+\exp \left(\delta_{0}+\delta_{1} h_{t}+\delta_{2} d_{t}^{i}+\delta_{3} d_{t}^{k}+\delta_{0} X_{t}+\rho_{4} \mu+\omega_{4} v_{t}\right)}
$$

Conditional on insurance and health, the individual chooses a long-term care arrangement. The probability that in individual chooses LTC alternative $k$ is

\footnotetext{
${ }^{15}$ This index is from McClellan (1998).
} 


$$
p\left(d_{t}^{k}=1 \mid \mu, v_{t}\right)=\frac{\exp \left(\varphi_{0 k}+\varphi_{1 k} h_{t}+\varphi_{2 k} d_{t}^{i}+\varphi_{3 k} A_{t}^{u}+\varphi_{4 k} A_{t}^{g}+\varphi_{5 k} Q_{t}^{S}+\varphi_{6 k} X_{t}+\rho_{5}^{k} \mu+\omega_{5}^{k} v_{t}\right)}{\sum_{k^{\prime}=0}^{3} \exp \left(\varphi_{0 k^{\prime}}+\varphi_{1 k^{\prime}} h_{t}+\varphi_{3 k} A_{t}^{u}+\varphi_{4 k} A_{t}^{g}+\varphi_{5 k} Q_{t}^{S}+\varphi_{6 k} X_{t}+\rho_{5}^{k^{\prime}} \mu+\omega_{5}^{k^{\prime}} v_{t}\right)} .
$$

The continuous values of the observed assets and gifts variables are given by

$$
A_{t}^{u}=\lambda_{0}^{u}+\lambda_{1}^{u} h_{t}+\lambda_{2}^{u} d_{t}^{i}+\lambda_{3}^{u} X_{t}+\rho_{6} \mu+\omega_{6} v_{t}+\varepsilon_{t}^{u}
$$

and

$$
A_{t}^{g}=\lambda_{0}^{g}+\lambda_{1}^{g} h_{t}+\lambda_{2}^{g} d_{t}^{i}+\lambda_{3}^{g} X_{t}+\rho_{7} \mu+\omega_{7} v_{t}+\varepsilon_{t}^{g}
$$

where $\varepsilon_{t}^{u}$ and $\varepsilon_{t}^{g}$ are i.i.d. error terms.

\section{B. Likelihood Function}

The likelihood function for individual $n$ reflects the probabilities of the observed insurance choice, the observed health state conditional on being alive, the observed LTC arrangement, asset allocation, and death over the four waves of the survey. $T_{n}$ is the number of periods the person is alive, or observed in the sample. Conditional on the unobserved heterogeneity, the contribution to the likelihood function of individual $n$ at time period $t$ is

$$
\begin{aligned}
& L_{n t}\left(\Theta \mid \mu, v_{t}\right)=p\left(d_{n t}^{i=3}=1 \mid \mu, v_{t}\right)^{\mathrm{I}\left(d_{n t}^{i=3}=1\right)} \times\left[\left(1-p\left(d_{n t}^{i=3}=1 \mid \mu, v_{t}\right)\right) \times \prod_{i=0}^{2} p\left(d_{n t}^{i}=1 \mid \mu, v_{t}\right)^{d_{n t}^{i}}\right]^{\mathrm{I}\left(d_{n t}^{i=3}=0\right)} \\
& \times f\left(h_{n t} \mid \mu, v_{t}\right) \times u\left(A_{n t}^{u} \mid \mu, v_{t}\right) \times g\left(A_{n t}^{g} \mid \mu, v_{t}\right) \times \prod_{k=0}^{3} p\left(d_{n t}^{k}=1 \mid \mu, v_{t}\right)^{d_{n t}^{k}} \\
& \times\left(1-p\left(h_{t+1}=H \mid \mu, v_{t}\right)\right)^{\mathrm{I}\left(h_{n t+1}<H\right)} p\left(h_{t+1}=H \mid \mu, v_{t}\right)^{\mathrm{I}\left(h_{n t+1}=H\right)}
\end{aligned}
$$

where $\Theta$ is the vector of parameters to be estimated, $\Theta=(\alpha, \beta, \delta, \varphi, \lambda, \rho), f(\cdot), u(\cdot)$, and $g(\cdot)$ are continuous density functions, $d_{n t}^{i}=1$ if individual $n$ is on insurance plan $i$ at time $t$, and $d_{n t}^{k}=1$ if individual $n$ chooses long-term care alternative $k$ in period $t$.

Significant correlation in unobservable individual traits and preferences across the decision 
variables and health presents itself as correlation among the errors in each equation, causing coefficients on endogenous explanatory variables to be biased if the correlation is unaccounted for. We approximate the unknown distribution of the heterogeneity with a discrete step function and "integrate out" with a weighted sum of probabilities. This discrete factor method, developed by Heckman and Singer (1984) and later extended to simultaneous systems by Mroz and Guilkey (1992) and Mroz (1999), imposes no distributional assumptions on the unobservables. Instead, it approximates the distribution of the heterogeneity by a finite number of mass points and probability weights that are estimated jointly with the other parameters of the model.

The analysis uses a panel data set collected on the same individuals from the AHEAD in 1993, 1995, 1998, and 2000. Since information on the state variables that explain observed decision variables in 1993 are unavailable, the 1993 information will serve as initial conditions $(t=0)$. Initial conditions for health, insurance choice, LTC arrangement, and assets must be modeled since the period $t$ decisions depend on these values. These initial conditions are modeled as reduced form equations and depend on the unobserved permanent heterogeneity $\mu$. Let $\mathrm{I}_{c}\left(R, \vartheta_{c}, \rho_{0 c} \mu\right)$ represent the probability of observing the value of the $c^{\text {th }}$ initial condition, where $R$ is a vector of explanatory variables, including valid exclusion restrictions, $\vartheta_{c}$ is the parameter vector, and $\rho_{0 c}$ is the factor loading on $\mu$. Thus, the likelihood function for each individual $n$ unconditional on the unobserved error components $\mu$ and $v_{t}$ is

$$
L_{n}(\Theta, \theta)=\sum_{a=1}^{A} \theta_{a}\left\{\prod_{c=1}^{C} \mathrm{I}_{c}\left(R, \vartheta_{c}, \rho_{0 c} \mu_{a}\right) \prod_{t=1}^{T_{n}}\left[\sum_{b=1}^{B} \theta_{b} L_{n t}\left(\Theta \mid \mu_{a}, v_{b t}\right)\right]\right\}
$$

where $\theta_{a}$ is the vector of probabilities on the A points of support of the heterogeneity distribution for the permanent unobservable, and $\theta_{b}$ is the vector of probabilities in the B points 
of support of the distribution of the time-varying heterogeneity. ${ }^{16}$ The likelihood function for a sample of size $\mathrm{N}$ is

$$
L_{n}(\Theta, \theta)=\prod_{n=1}^{N} L_{n}(\Theta, \theta) \text {. }
$$

\section{Description of Data}

The data for this project are from the 1993, 1995, 1998, and 2000 waves of the Assets and Health Dynamics of the Elderly (AHEAD). The AHEAD survey is a national panel survey composed of households in which the head of household is at least 70 years of age. We observe three transitions, from 1993 to 1995, 1995 to 1998, and 1998 to 2000. The initial survey data, in 1993, are treated as initial conditions.

Included in the analysis are individuals who: 1) provide a core interview all four waves; or 2) provided a core interview in periods when alive and surviving relatives answer the exit survey in the year the individual dies. ${ }^{17}$ Observations that do not meet criteria 1) or 2) are dropped so that a continuous panel of observations can be constructed. Out of 8,449 persons, there are 7,004 that meet these criteria. Also dropped are the 162 persons under age 65 and 35 persons who are missing health data in all waves. After these deletions there are 6,807 persons, for a total of 25,011 person-period observations.

\section{A. Individual Variables}

Summary statistics for decision variables, by health category, are shown in Table 1. Additional information on the sample, not shown in the table, reveals that in $199512.0 \%$ of the sample is

\footnotetext{
${ }^{16}$ There is no determinant method for choosing the number of points of support for each type of unobserved heterogeneity. The final specification is chosen by observing the change in estimates and the likelihood function value as more points of support are added. The final specification for this model has one permanent and one timevarying factor, where the permanent factor has four points of support and the time-varying factor has three points of support. Identification issues are discussed in Appendix A.

${ }^{17}$ If an individual dies between waves, the AHEAD sample design provides for exit interviews with a surviving spouse, child, or other informant. Of the 6,807 persons included in this analysis, there is a $22 \%$ rate of attrition due to death from 1993 to 2000.
} 
enrolled on Medicaid, while these numbers rise to $12.8 \%$ and $14.3 \%$ in 1998 and 2000, respectively. The percent of persons receiving each type of long-term care is very similar among those with no insurance and private insurance. That is, in 1998 the percent of people receiving paid home care without insurance, with private insurance without long-term care coverage and with private insurance with long-term care coverage is $10.0 \%, 8.6 \%$, and 9.6\%, respectively; and the percent of people living in a nursing home in the same insurance categories is $5.3 \%, 6.0 \%$, and 4.5\%. Yet, of persons enrolled on Medicaid, 15.5\% are receiving paid home care and 27.4\% are living in a nursing home. ${ }^{18}$

AHEAD asks detailed questions on the type and quantity of long-term care. Individuals who were in a nursing home in the first wave were not included in the survey. However, at subsequent waves, Wave 1 respondents who are institutionalized continue to be interviewed. Overall, 5.6\% of the sample lives in a nursing home in 1995, 11.5\% in 1998, and 13.5\% in 2000.

The asset variables in the AHEAD are collected at the household level. However, one can distinguish assets of the elderly couple (person) in the household from the assets of other household members. Our measure of unprotected assets is the sum of stocks, bonds, savings accounts, business assets, checking and CD accounts, trusts, IRAs, value of secondary real estate, and other assets, minus all debts. In the empirical model, any person reporting negative assets is assigned a value of zero assets. Our gifts measures include gifts made to children, grand-children, friends and others in the preceding year and gifts to charity. We model both the probability of any assets (and any gifts) and the level of assets (or gifts), if any.

\section{B. Eligibility Policy Variables}

The policy variables used in estimation are defined in Table 2. We differentiate between

\footnotetext{
${ }^{18}$ Individuals are coded as having received formal or informal care in the community only if they received care at least twice a week (on average). Formal care is paid and informal care is unpaid. A person is also coded as having received informal care if she received help with three or more ADLS on a regular basis.
} 
policy variables that determine eligibility for Medicaid and those that affect availability and quality of Medicaid services for the elderly in a state. Our measure of the generosity of Medicaid’s eligibility rules for nursing home care follows Gruber’s (Currie, 1996; Gruber, 1999) measure in his work on single women and children. We model the impact of Medicaid's eligibility criteria for nursing home care by determining the amount of expected nursing home expenditures that would be covered by the Medicaid program for a given household, in a given state and time period. Specifically, for each person, we determine a likelihood of being eligible for nursing home care that is a function of the legislative environment in a state and year but not related to the demographics of that state (NH Eligibility). ${ }^{19}$ Then we proxy the benefits of eligibility by the average cost of nursing home care in a state and year. The final measure (NH Generosity) is the probability of nursing home eligibility multiplied by the expected spending on care for two years (based on the fact that there are two years between the AHEAD survey waves). This measure of eligibility dollars will vary across households due to differences in state eligibility rules that differ by household characteristics, and the average costs of care in the state.

We use two variables to capture the theory that persons who hold assets that are closer to the asset limit may be more (or less) willing to dispose of assets in order to become eligible for Medicaid. These are the log amount of assets that one would have to spend/transfer or otherwise dispose of in period $t-1$ in order to be eligible for Medicaid nursing home coverage in period $t$ (NH \$ Loss), and the log amount of assets calculated similarly for Medicaid HCBS coverage (HCBS \$ Loss).

Within each state the asset limit depends on marital status. If an individual is single the asset

\footnotetext{
${ }^{19}$ For each year we categorize the entire sample by the four education categories in Table 1 . Then we compute the eligibility of all persons for each state's rules in that year. The average eligibility is then measured in each marital status/education/age/state/cell to get a cell-specific eligibility measure. Thus for each year there is an average eligibility by state, marital status, education level and age category. These averages are then assigned to the whole sample. There are four age categories used for this procedure: 70-76, 76-81, 81-85, and over 85.
} 
limit is the standard limit for singles shown in Appendix Table A1. However, if the elderly individual who is applying for Medicaid is married, he/she may transfer a specified amount of assets to the spouse (if the spouse is not also applying for Medicaid). After transferring assets to his/her spouse, the elderly individual who is applying for Medicaid may not have assets higher than the asset limit for single individuals. For example, if the asset limit for a single individual is $\$ 2,000$, and the maximum spousal protection limit is $\$ 87,000$, the asset limit for the spouse applying for care is $\$ 2,000+\$ 87,000$, since the non-Medicaid spouse can retain up to $\$ 87,000$.

An important policy issue in a state's provision of HCBS is to ensure that a Medicaid recipient and spouse, if present, have enough wealth to live on after their contribution (if any) to home care. If single, the policy variables that determine the amount of wealth one can retain while receiving Medicaid coverage are the asset limit for HCBS eligibility and an income 'maintenance needs allowance (MNA).' For example, suppose that the $M N A_{t, s}$ in state $s$ at time $t$ is $\$ 400$ and the income limit is $\$ 1,200$. Also, the price of home- and community-based care per month is $\$ 800$. A person who has an income of $\$ 1,100$ per month must spend $\$ 700$ $\left(\$ 1100-M N A_{t, s}\right)$. After the individual has paid $\$ 700$, Medicaid will cover the rest of the cost of care, which is $\$ 100$ (i.e., $\$ 800$ - $\$ 700)$.

If married, the elderly individual receiving Medicaid HCBS coverage may keep up to the asset limit and $M N A_{t, s}$, and the spouse may keep up to the maximum protected spousal income and up to the maximum spousal protection asset limit; these limits are shown in Appendix Table A2. Our policy variable, the 'HCBS \$ Allowable' was constructed in the same manner as Medicaid NH eligibility for nursing home care: the residual wealth is computed for each person for each state's policies in each year. Then the average residual wealth for each marital status/education/ age/state/cell is assigned to the entire sample for their specific state of residence. HCBS \$ Loss 
is analogous to NH \$ Loss and is the amount of income and assets an individual would have to lose to become eligible for Medicaid HCBS.

\section{Supply-Side Policy Variables}

States also influence the availability and quality of nursing home care by setting reimbursement rates to providers and by enforcing Certificate of Need (CON) restrictions and/or moratoriums that restrict the construction of nursing home beds at the state level. ${ }^{20}$ The number of nursing home beds per 1000 persons age 65 and over captures the effect of any limitation on supply of nursing home beds (Beds/1000 Elderly). In 1998 the number of beds per 1000 elderly ranged from 20 in West Virginia to 79 in Indiana, as seen in Appendix Table A3.

Appendix Table A3 also lists the Medicaid and out-of-pocket payment rates to nursing homes in 1998, across states. As discussed in previous literature, Medicaid reimburses nursing facilities at a rate below the private-pay and Medicare payment rate to help lower Medicaid costs of nursing home care (Wiener, 1996; Gertler, 1992). This discrepancy could lead to access and quality problems for Medicaid patients. Empirical evidence has suggested that as the payment differential between private pay and Medicaid patients widens, access problems worsen for Medicaid beneficiaries (Ettner, 1993; Hoerger et al, 1996).

We define a measure of the difference between out-of-pocket costs and Medicaid payment rates for nursing home care (NH Revenue Loss). This nursing home revenue loss is an individual-specific measure of the difference between the revenues a nursing home would receive if a person never qualified for nursing home care, and the nursing home's projected

\footnotetext{
${ }^{20}$ The premise of Certificate of Need or moratorium restrictions as a method of cost-control is based on Roemer's Law, which holds that the availability of open-ended, third-party reimbursement allows demand for health care services to expand to meet whatever supply is available (Wiener et al., 1998). Thus, if a nursing home bed is built, there is a significant probability that it will be filled by a Medicaid patient, which will lead to higher program costs. Research evidence also suggests a significantly positive relationship between nursing home use and the ratio of number of nursing home beds to the elderly population (Hoerger et al., 1996; Greene and Ondrich, 1990; Liu et al., 1991; Greene et al., 1993).
} 
revenues if a person becomes eligible for nursing home care during a stay (one wave of the AHEAD data covers two years). This measure of revenue loss takes into account when the person would become eligible, predicted probabilities that a person will be alive in each period from a hazard analysis, and Medicaid’s nursing home reimbursement rates in the state. ${ }^{21}$

The financial eligibility requirements for mandatory home health services and the personal care option are identical to those for nursing home care, so we model the generosity of a state's expenditures on these two services as the ratio of total spending on home health and personal care to the total amount of spending on nursing home care $(\mathrm{HH}+$ Personal \$/NH\$).

The HCBS waiver program is the primary mechanism for providing Medicaid funded, community-based, long-term care services. States' determination of the number of persons to cover under a waiver is an important factor in the availability of home care services. To approximate the availability of HCBS Waiver programs for the elderly, we use the average HCBS expenditure per eligible elderly person in the state (HCBS \$/Elig. Elderly). We proxy eligibility with receipt of Supplementary Security Income.

Although Medicare only covers short stays in a nursing home and limited home health services, there is one aspect of Medicare coverage of home health that is important in the context of this study. ${ }^{22}$ In October 1997 there was a substantial change in Medicare's reimbursement policy which has been associated with a large decline in the provision of home care (McKnight, 2002). The reimbursement policy change involved the imposition of average per-patient reimbursement caps to home health care agencies. ${ }^{23}$ This policy change could give home health

\footnotetext{
${ }^{21}$ There also may be a perception by individuals that they could not get into a nursing home under Medicaid coverage. This measure assumes no spend-down or saving behavior by the individual.

${ }^{22}$ Medicare covers care in a skilled nursing facility for up to 100 days, and only for persons who need a skilled level of care and who have had a prior hospital stay that lasted at least 3 days. Although Medicare does not require a copayment for the first 20 days in a nursing home, after the first 20 days the co-payments (\$97 a day in 2000) are not very different from the out-of-pocket cost of care in many facilities.

${ }^{23}$ In particular, caps were constructed as a weighted average of the historical costs per home care user in each agency and the mean historical costs per home care user in each agency's census division.
} 
agencies an incentive to reduce per-patient costs. To control for the effects of this change in Medicare reimbursement to home health care agencies, we include the change in Medicare's average payment per patient from the previous period, by state, interacted with a dummy variable indicating the post-policy period (Medicare \$ Change). Thus, for 1995 this variable is zero. Medicare payment information is from the National Association for Home Care and Hospice Organization. $^{24}$

\section{Results}

Tables 3a - 3c show selected coefficient estimates from the heterogeneity model. ${ }^{25}$ Due to the underlying dynamics of the model, interpretation of these point estimates is difficult but signs and significance provide some information about the effects of each variable. To provide a better understanding of the effects of variables we also present the impacts of simulated changes in state Medicaid policy variables from 1995 to 2000 in Table 5.

There are many questions that could be explored with this model. In this paper, our discussion focuses on the original objectives posed in the introduction: What are the primary determinants of asset levels and choice of insurance; and what is the relative importance of Medicaid policies in the dynamic decision-making related to these outcomes.

\section{A. Medicaid}

According to the results in Tables 3a-3c, persons who are enrolled in Medicaid are more likely to be enrolled in Medicaid the following period, relative to those with no supplemental insurance, are more likely to be receiving formal home care or nursing home care than no care, are less likely to have assets or give gifts, and have lower assets, if any. All results are significant within a reasonable level, and consistent with previous literature and the theory in

\footnotetext{
${ }^{24}$ http://www.nahc.org/NAHC/LegReg/Crisis/crisishh.html

${ }^{25}$ Results for all coefficient estimates are available from the authors upon request.
} 
Section III. ${ }^{26}$ The effects of Medicaid policy variables on Medicaid enrollment and other choice variables are discussed below.

\section{B. Assets}

Assets from the previous period affect the insurance, long-term care, and asset and gift equations quadratically. Overall the signs of the estimates are as expected: lag assets are negatively related to Medicaid enrollment; negatively related to receiving informal home care or nursing home care; and positively related to asset and gift levels. Lag assets have no significant effect on formal home care. In Table 3b, lower asset levels are significantly related to receiving Medicaid coverage or having worse health, as are the following demographic characteristics (not shown): female, Hispanic, non-white, single, lower education levels, and higher numbers of children.

\section{Medicaid Eligibility Policies}

\section{Medicaid Nursing Home Generosity}

NH Generosity has a positive effect on the probability of Medicaid enrollment, significant at the one percent level. In Table 3b, this generosity also has a significantly positive effect on the probability of holding positive assets and continuous asset levels, and an insignificant effect on gifts. These results could be interpreted as follows: Higher values of NH Generosity result from a combination of more generous Medicaid eligibility rules and higher costs of nursing home care. In states that have more generous eligibility rules relative to other states, people are allowed to qualify for Medicaid while holding higher asset levels. Thus, persons in states with more generous eligibility rules may choose to hold as high of assets as allowed under Medicaid coverage. In other words, these results may suggest that if persons are allowed to hold more

\footnotetext{
${ }^{26}$ Not shown is that persons who are Hispanic, non-white, older, or single are more likely to be enrolled in Medicaid; these results are also consistent with previous literature.
} 
wealth under Medicaid coverage, they will choose to do so. ${ }^{27}$

\section{HCBS Dollars Allowable}

The average dollar amount of income and assets one may retain while receiving Medicaid HCBS coverage is insignificantly related to the probability of Medicaid enrollment. This supports previous arguments discussed in Section II that the availability of HCBS coverage within a state, rather than the HCBS financial eligibility rules, may be more relevant to the Medicaid enrollment decision. Although the retained wealth allowable under HCBS coverage is significantly positively related to the probability of holding positive assets, it is significantly negatively related to continuous asset levels. Whereas Medicaid nursing home generosity encouraged people to hold more assets, Medicaid home care generosity has a negative relationship with assets. This indicates that spend-down behavior for HCBS eligibility could be present - as people are allowed to hold more wealth under HCBS coverage, that coverage is more appealing and people spend down to improve their chances of eligibility.

\section{Dollar Loss Variables}

The nursing home and HCBS dollar losses are constructed as the difference between lag assets and the Medicaid asset limits for nursing home care and HCBS, respectively. Our theory suggests that persons whose assets were closer to the eligibility limits in the previous period would be more likely to be enrolled in Medicaid in the current period. However, both dollar loss measures are insignificantly related to the probability of Medicaid enrollment. This does not suggest that spend down behavior may not be occurring, but that those persons currently enrolled in Medicaid held a wide range of assets in the previous period. This may also be a reflection of the two to three year gap in the data between last period's observable assets and current period enrollment in Medicaid.

\footnotetext{
${ }^{27}$ We thank the seminar participants at University of Canterbury for drawing our attention to this possibility.
} 
The individual-specific dollar loss necessary for Medicaid eligibility for nursing home care, based on assets in the previous period, is significantly positively related to asset levels and negatively to gifts. In contrast, the dollar loss necessary for Medicaid HCBS eligibility is significantly negatively related to asset levels and positively related to gifts. An example may help to interpret the meaning of these coefficients. Consider two single individuals living in two different states. Both have assets of $\$ 15,000$ in period $t .^{28}$ The person in state $a$ faces an asset limit of $\$ 10,000$ while the person in state $b$ faces an asset limit of $\$ 2,000$. Assume both are eligible based on income eligibility and level-of-care requirements. The person in state $a$ faces a dollar loss of \$5,000 in order to obtain Medicaid eligibility, while the person in state $b$ faces a $\$ 13,000$ dollar loss in order to obtain Medicaid eligibility. If we view these asset limits as the resource standards for nursing home coverage, then the person in state $a$, who has less assets to lose in order to qualify for Medicaid, will hold less assets in the current period (since there is a positive relationship between nursing home dollar loss and asset levels). This suggests that persons who have less assets to lose in order to obtain Medicaid coverage of nursing home care in period $t$, will choose to hold less assets in period $t+1$; in other words, persons who face relatively higher asset limits may lower assets in order to qualify for Medicaid.

On the other hand, if we view these asset limits as resource standards for HCBS coverage, then the person in state $a$ is more likely to hold higher assets in the current period. This could be interpreted as saying that people who are closer to obtaining Medicaid eligibility (dollar loss for obtaining eligibility is lower), will hold higher asset levels.

Why would the individual-specific measure of dollar loss necessary for HCBS coverage have a negative effect on asset levels when the average measures of HCBS generosity have the opposite effects? Perhaps the answer is related to the fact that in many states the elderly are on waiting

\footnotetext{
${ }^{28}$ Note that both lag assets and lag assets squared are included in the estimation, thus controlling for assets in the previous period.
} 
lists for HCBS coverage. That is, their state of residence has an HCBS waiver program for the aged, but it only covers a limited number of persons and when that limit is met, remaining applicants must wait for eligibility. Thus, on average, states that have more generous eligibility and residual wealth rules will see elderly lower asset levels, given the negative coefficient on average HCBS generosity within a state in the asset equation; but individually, an elderly person will not want to lower assets to the low levels necessary for Medicaid HCBS eligibility until that coverage is available. In fact, the summary statistics in Table 1 show that the percentage of people in our sample reporting poor health increases with time, but the percent with Medicaid remains fairly constant.

\section{Medicaid Supply-Side Variables}

\section{Nursing Home}

In Table 3a, the number of beds per elderly within a state is significantly positively related to Medicaid enrollment and the probability of living in a nursing home (relative to no care); and significantly negatively related to asset levels. Greater nursing home revenue losses, indicating lower Medicaid reimbursement rates relative to private pay costs, are significantly negatively related to the probability of receiving Medicaid coverage, as expected, but have an insignificant effect on the probability of nursing home care and are significantly negatively related to asset and gift levels. Theory indicates that as the nursing home revenue loss decreases, the probability of Medicaid enrollment would increase, as the estimates increase. As this occurs individuals should lower asset levels, perhaps by increasing gift levels, in order to receive Medicaid coverage. Although gift levels do increase as the revenue loss decreases, why assets increase is unclear. 
Both of the supply variables for Medicaid home care, the ratio of spending on home care to nursing home care and HCBS spending per eligible elderly, have a significantly positive relationship with Medicaid enrollment, as predicted. Although the long-term care ratio has a significantly positive relationship with the receipt of paid home care and significantly negative relationships with asset and gifts levels, the average HCBS spending is insignificantly related to these both receipt of paid home care and asset levels.

\section{E. Simulations}

Given our estimated dynamic structural model we conduct several simulations in order to investigate the impacts of the policy variables on behavior over time. The simulation procedure involves random assignment of permanent heterogeneity at the beginning of 1995 and she retains this assignment all subsequent periods. We also randomly draw from the time-varying heterogeneity distribution at the beginning of 1995, 1998, and 2000 for each person. Based on the point estimates in each equation, each individual's observed explanatory variables, and the random draws from the i.i.d. error distributions, as well as the unobserved permanent and timevarying individual heterogeneity distributions, predictions are made for the 1995 values of Medicaid, insurance, health, long-term care, assets, gifts, and deceased outcomes sequentially, accounting for current period realizations that influence subsequent current period choices (i.e., current period health affects current period long-term care utilization). Using these simulated outcomes, we then recalculate each individual's Medicaid eligibility status ${ }^{29}$ and, depending on the policy simulation, policy variables for 1998. We also update the endogenous right-hand side variables for 1998 based on the simulated outcomes from 1995. The same procedure is followed from 1998 to 2000. We perform 50 replications of each individual observed in our sample in 1995. Outcomes are averaged over all person replications alive in the year of interest.

\footnotetext{
${ }^{29}$ The Medicaid eligibility status must be re-calculated because a dummy variable equal to one if Medicaid eligible is included in the insurance equation.
} 
Before discussing the results of changes in policy variables, we present how accurately the model predicts the observed outcomes. In Table 4, we show the observed averages from the data, simulated behavior obtained with the above method without updating the right-hand side variables (i.e., using observed values of all right-hand side variables), simulated behavior when right-hand side variables are updated (i.e., using simulated values of all right-hand side variables), and simulations by mass point. ${ }^{30}$ The model fits the observed outcomes quite well. For dichotomous variables most of the updated simulations are within two percentage points of the observed outcomes; and for the continuous variables, all updated simulations are within 0.6 (log) of the observed outcomes.

Table 5a provides baseline behavior obtained using the estimated model and updating all explanatory endogenous variables (the table reports Medicaid enrollment and assets and gifts only). This simulated behavior is categorized by individuals' observed marital status and asset category in 1993 . The discrete asset categorization corresponds roughly to the $10^{\text {th }}, 35^{\text {th }}$, and $70^{\text {th }}$ percentiles of the asset distribution of married individuals (i.e., cutoffs of $\$ 0, \$ 15,000$, and $\$ 150,000$ ) and the $20^{\text {th }}, 50^{\text {th }}$, and $80^{\text {th }}$ percentiles of the asset distribution of singles (i.e., cutoffs of $\$ 0, \$ 10,000$, and $\$ 100,000$ ). The pattern of results is identical to that found in the observed data: single persons are more likely to have Medicaid coverage than married persons, they are less likely to save and gift, and their asset holdings are smaller. Average asset levels of all individuals increase over time in each category. ${ }^{31}$ However, the probability of positive assets falls. $^{32}$

\footnotetext{
${ }^{30}$ Right-hand side variables that must be updated are the endogenous right-hand side variables, Medicaid eligibility status, and the difference between lag assets and the Medicaid asset limits. Predictions by mass point do not include updates of the right-hand side variables.

${ }^{31}$ The latter result is also evident in the observed data, and initially may appear to contract the traditional life-cycle model prediction that elderly persons decrease assets over time. We do not deflate dollar values in the analysis due to the fact that asset and income values must be compared to the nominal dollar limits set by each state each year. However, we examined the real value of assets among those individuals who are alive all years in our data, and asset levels are a bit more constant between 1998 and 2000, but indicate increases between 1995 and 1998. In addition to
} 
We then introduce changes in various Medicaid policies and re-evaluate behavior over time (to be compared with the baseline). In Table 5b, Medicaid asset and spousal protection limits for nursing home coverage are doubled in each period (Simulation 1). These institutional changes alter some of the Medicaid policy variables in our analysis. In particular, Medicaid $\mathrm{NH}$ Generosity and Eligibility increase, and the individual-specific dollar loss necessary for Medicaid eligibility (NH \$ Loss) decreases. The average simulated behavioral outcomes are also categorized by the 1993 marital status and asset category to determine how behavior differs by these characteristics.

Medicaid enrollment increases in all years, but the increase is small (between 0.1 and 1.6 percentage points). Single persons have increases in enrollment that are equal to or greater than married persons in the same asset categories. The increase in enrollment probabilities increases over time, for all marital status-asset combinations. These relatively small increases in Medicaid enrollment suggest that other influences, such as welfare aversion and/or bequest motives, create disincentives for Medicaid participation. The simulated increase in nursing home asset limits results in higher asset levels and no significant change in gift levels. These results are consistent with the coefficient estimates in Table 3. Again we theorize that increases in Medicaid nursing home generosity and decreases in the individual dollar loss required for eligibility lead to increases in assets because as people are allowed to hold more assets under Medicaid coverage, they will choose to do so. This theory is reinforced by the fact that although persons in the 'high’ asset category increase assets by the largest dollar amount, by 1998 and 2000 persons in the zero and low asset categories have larger percentage increases in assets than those in the

the large increases in stock market value during these years, we believe this result occurs in the full sample because individuals with the lowest wealth also have the poorest health, on average. Thus as persons who are poorest in health decease, the average asset levels for the living increase.

${ }^{32}$ We should also note that it has been reported that there is more measurement error in the 1993 AHEAD asset data than in subsequent waves. Since our categorization is based on 1993 assets, the asset increases over time may reflect better measurement of assets in later years. 
'high’ category; this result holds for both single and married persons.

In the next simulation the asset and spousal protection limits for Medicaid coverage of homeand community-cased services (HCBS) are doubled (Table 8c, Simulation 2). These increases cause average HCBS \$ Allowable to increase and the individual-specific dollar loss necessary for eligibility to decrease. Although federal law requires spousal protections for nursing home care, it is an option for HCBS coverage. Thus these simulations are expected to have a larger impact on the predicted outcomes, since as seen in Appendix Table A2, many states do not have spousal protection limits under HCBS coverage.

The results are consistent with the point estimates - the increased generosity of Medicaid eligibility rules for HCBS coverage leads to decreases in Medicaid enrollment and asset levels in all categories. However we must recall that the variables increased by this simulation, HCBS \$ Allowable and HCBS \$ loss, were insignificantly related to both Medicaid enrollment and the probability of formal care use. Thus only the simulated changes in asset levels should be considered robust, and these indicate a spend-down behavior to obtain HCBS eligibility when the eligibility rules are more generous.

Based on the point estimates in Table 3, the long-term care spending ratio is significantly related to assets and gifts, and is also significantly positively related to Medicaid enrollment and the probability of paid home care use is the long-term care spending ratio. We simulated a fifty percent increase in this ratio for each state (Table 8d, Simulation 3). Medicaid enrollment increases, although by less than one percentage point in all categories. In 1995, 1998, and 2000 asset levels decrease between 3.3\% and 4.9\%; 5.1\% and 7.2\%; and 6.5\% and 8.9\%, respectively.

\section{Conclusion}

The national budget released by the Bush administration in February 2006 proposes to reduce Medicaid spending by about $\$ 60$ billion over the next decade. Included in that plan are measures 
expected to reduce assets transfers by the middle- and upper-class elderly who may try to impoverish themselves in order to receive Medicaid coverage of long-term care. Our goal was to use existing data on Medicaid and assets to gain an understanding of how differences in Medicaid rules across states and time influence utilization and costs. Therefore, we undertook a comprehensive analysis of elderly persons’ insurance, health, long-term care and savings decisions over time.

Our results indicate that Medicaid enrollment is significantly related to more generous eligibility requirements for nursing home care, higher number of beds per elderly within a state, and smaller differences between Medicaid payment rates to nursing home and the private-pay costs. In states where people are allowed to qualify for Medicaid nursing home coverage while holding more wealth, they will choose to hold more assets.

Our results also indicate that higher levels of state spending on mandatory and personal care, relative to nursing home care, are positively related to Medicaid enrollment and receipt of formal home care, and negatively related to assets. Medicaid eligibility rules for HCBS had no effect on Medicaid enrollment, but were significantly related to lower asset levels, suggesting that people may spend-down for HCBS coverage.

Given our estimated dynamic structural model we conducted several simulations in order to investigate the impacts of the policy variables on behavior over time. Doubling Medicaid eligibility limits for nursing home coverage increases Medicaid enrollment only slightly. This increase in Medicaid eligibility generosity results in higher asset levels, but lower probabilities of any assets, suggesting that people do modify savings behavior in response to Medicaid limits. In contrast, increases in asset limits for Medicaid coverage of HCBS cause asset levels to decrease, suggesting a spend-down effect.

We conclude that the generosities of Medicaid policy structures do influence elderly persons 
decisions on whether to enroll in Medicaid for long-term care coverage; including eligibility policies, HCBS services offered, home care spending, restrictions on construction of nursing home beds, and reimbursement rates to nursing homes. As the new asset transfer rules in the Deficit Reduction Act are implemented across all states, elderly persons must be careful of any asset transfers made up to at least five years before their health deteriorates to where they need long-term care and perhaps Medicaid coverage. 
Table 1. Descriptive Statistics, by Discrete Health Categorization

\begin{tabular}{|c|c|c|c|c|c|c|c|c|c|c|}
\hline \multirow{2}{*}{\multicolumn{2}{|c|}{$\begin{array}{l}\text { Proportion in each } \\
\text { Health Category }{ }^{1} \\
\end{array}$}} & \multicolumn{3}{|c|}{1995} & \multicolumn{3}{|c|}{1998} & \multicolumn{3}{|c|}{2000} \\
\hline & & $\begin{array}{c}\text { Good } \\
70.8 \\
\end{array}$ & $\begin{array}{l}\text { Fair } \\
16.7\end{array}$ & $\begin{array}{l}\text { Poor } \\
12.5\end{array}$ & $\begin{array}{c}\text { Good } \\
65.1 \\
\end{array}$ & $\begin{array}{l}\text { Fair } \\
17.0\end{array}$ & $\begin{array}{l}\text { Poor } \\
17.8\end{array}$ & $\begin{array}{c}\text { Good } \\
60.8 \\
\end{array}$ & $\begin{array}{l}\text { Fair } \\
18.0\end{array}$ & $\begin{array}{l}\text { Poor } \\
21.2 \\
\end{array}$ \\
\hline \multicolumn{11}{|c|}{ Endogenous Variables ${ }^{2,3}$} \\
\hline$d_{t}^{i=3}$ & On Medicaid & 8 & 16 & 30 & 7 & 14 & 31 & 8 & 16 & 30 \\
\hline \multirow[t]{4}{*}{$d_{t}^{i}, i=0,1,2$} & $\begin{array}{l}\text { Supplemental Insurance } \\
\text { If not on Medicaid }\end{array}$ & & & & & & & & & \\
\hline & Medicare Only & 25 & 24 & 24 & 30 & 28 & 26 & 31 & 30 & 27 \\
\hline & Private Insurance No LTC & 58 & 55 & 42 & 54 & 52 & 39 & 52 & 48 & 40 \\
\hline & Private Insurance with LTC & 9 & 5 & 4 & 8 & 6 & 4 & 8 & 6 & 3 \\
\hline$h_{t}$ & Health Index & 0.30 & 2.92 & 4.11 & 0.31 & 2.97 & 4.16 & 0.26 & 2.92 & 4.17 \\
\hline$p\left(h_{t+1}=H\right)$ & Death & 11.0 & 8.0 & 8.4 & 10.2 & 14.1 & 25.7 & 8.1 & 15.6 & 34.2 \\
\hline \multirow[t]{5}{*}{$d_{t}^{k}, k=0,1,2,3$} & LTC Arrangement & & & & & & & & & \\
\hline & No LTC & 92 & 63 & 14 & 89 & 51 & 12 & 91 & 59 & 14 \\
\hline & Unpaid Home Care & 4 & 27 & 42 & 4 & 29 & 29 & 6 & 17 & 22 \\
\hline & Paid Home Care & 1 & 5 & 20 & 1 & 10 & 24 & 2 & 8 & 21 \\
\hline & Nursing Home & 3 & 5 & 23 & 6 & 9 & 35 & 2 & 16 & 44 \\
\hline$p\left(A_{t}^{u}>0\right)$ & Any Unprotected Assets & 88 & 82 & 74 & 90 & 85 & 72 & 90 & 82 & 69 \\
\hline$A_{t}^{u} \mid A_{t}^{u}>0$ & Unprotected Assets (000's) & 291 & 157 & 144 & 347 & 244 & 217 & 446 & 289 & 245 \\
\hline$p\left(A_{t}^{g}>0\right)$ & Any Gifts & 53 & 44 & 31 & 55 & 43 & 25 & 54 & 46 & 30 \\
\hline$A_{t}^{g} \mid A_{t}^{g}>0$ & Gifts (000's) & 9.2 & 11.6 & 11.2 & 68.1 & 15.0 & 46.2 & 16.7 & 97.2 & 191.5 \\
\hline \multicolumn{11}{|c|}{ Exogenous Variables } \\
\hline \multirow[t]{10}{*}{$X_{t}$} & Female & 60 & 68 & 71 & 60 & 67 & 74 & 62 & 70 & 70 \\
\hline & Non-Caucasian & 13 & 16 & 21 & 12 & 15 & 20 & 12 & 14 & 20 \\
\hline & Hispanic & 5 & 6 & 6 & 5 & 5 & 8 & 5 & 6 & 7 \\
\hline & No High School Degree & 38 & 49 & 61 & 35 & 47 & 60 & 34 & 42 & 56 \\
\hline & High School Graduate & 32 & 28 & 22 & 33 & 29 & 24 & 34 & 31 & 24 \\
\hline & Some College & 16 & 13 & 9 & 17 & 14 & 9 & 18 & 16 & 11 \\
\hline & College Graduate & 13 & 9 & 8 & 14 & 10 & 7 & 14 & 11 & 9 \\
\hline & Single & 45 & 57 & 66 & 42 & 55 & 69 & 53 & 64 & 69 \\
\hline & Age & 78 & 81 & 83 & 80 & 82 & 85 & 81 & 84 & 85 \\
\hline & Number of Children & 2.5 & 2.6 & 2.6 & 2.8 & 2.8 & 2.8 & 2.9 & 2.8 & 2.8 \\
\hline \multicolumn{11}{|c|}{$\begin{array}{l}{ }^{1} \text { Health categorizations: Good: No ADL difficulties and less than } 3 \text { IADL difficulties; Fair: Either a) No ADL } \\
\text { difficulties and difficulty with } 3 \text { or more IADLs; or b) difficulty with } 1 \text { or } 2 \text { ADLs and less than } 3 \text { IADL diffic } \\
\text { Poor: Either a) Difficulty with } 3 \text { or more ADLs or b) Difficulty with } 1 \text { or } 2 \text { ADLs and } 3 \text { or more IADLs. } \\
{ }^{2} \text { Numbers represent percent of the sample in each category in most cases. Means are reported for health index, } \\
\text { assets if any and gifts if any , and for age and number of children. } \\
{ }^{3} \text { Appendix Table A5 lists and defines right-hand side variables constructed from the endogenous variables. }\end{array}$} \\
\hline
\end{tabular}


Table 2. Medicaid Policy Variables

Eligibility Variables:

Enrollee $\quad$ Indicator $=1$ if individual has Medicaid coverage in the current period.

NH Eligibility Average probability of eligibility for Medicaid coverage of nursing home care for a marital status/age/education cell.

NH Generosity The product of average Medicaid eligibility probability within a state for a marital status/age/education cell and the average cost of nursing home care in the state for two years.

NH \$ Loss

Individual quantity of assets above eligibility limits for obtaining Medicaid eligibility for nursing home care, based on assets in the previous period and Medicaid eligibility policies in state of residence.

Average dollar amount of income and assets one may retain while receiving Medicaid HCBS

HCBS \$ Allowable coverage within a state, for a marital status/age/education cell.

Average dollar loss in assets necessary to obtain Medicaid HCBS coverage within a state for a marital status/age/education cell.

HCBS \$ Loss

Supply-Side Variables:

Beds/1000 Elderly Number of Nursing Home beds per 1000 Elderly.

NH Revenue Loss Amount of lost revenue to a nursing home from accepting the Medicaid payment rate for a patient rather than the private pay rate (over two years).

HH+Personal \$ / NH \$ State’s ratio of total Medicaid dollars spent on Mandatory Home Care and Optional Personal care to total dollars spent on Nursing Home care.

HCBS \$ /Elig. Elderly Amount of spending on optional home- and community-based waivers for the elderly per eligible elderly. An elderly person is eligible if enrolled in SSI. Not all those eligible are enrolled.

Medicare \$ Change Change in average per-patient Medicare payment to home health agencies as part of the BBA 1997; i.e. a value of ' 37 ' means the payment dropped by $37 \%$. 
Table 3a. Selected Parameter Estimates from the Equation System with Heterogeneity Outcome: Medicaid, Health Insurance, and Long-Term Care Arrangement

\begin{tabular}{|c|c|c|c|c|c|c|}
\hline \multirow[b]{2}{*}{ Explanatory Variables } & \multirow[b]{2}{*}{ Medicaid } & \multicolumn{2}{|c|}{ Other Insurance } & \multicolumn{3}{|c|}{ Long-Term Care Arrangement } \\
\hline & & $\begin{array}{c}\text { Private } \\
\text { No LTC }\end{array}$ & $\begin{array}{l}\text { Private } \\
\text { w/ LTC }\end{array}$ & $\begin{array}{c}\text { Informal } \\
\text { Care }\end{array}$ & $\begin{array}{c}\text { Formal } \\
\text { Care }\end{array}$ & $\begin{array}{c}\text { Nursing } \\
\text { Home }\end{array}$ \\
\hline NH Generosity/10000 & $\begin{array}{c}0.072 \\
(0.021)\end{array}$ & $\begin{array}{l}-0.069 \\
(0.012)\end{array}$ & $\begin{array}{c}-0.148 \\
(0.025)\end{array}$ & $\begin{array}{c}-0.004 \\
(0.028)\end{array}$ & $\begin{array}{c}0.005 \\
(0.039)\end{array}$ & $\begin{array}{c}0.044 \\
(0.034)\end{array}$ \\
\hline $\ln (\mathrm{NH} \$$ Loss $)$ & $\begin{array}{c}0.014 \\
(0.020)\end{array}$ & $\begin{array}{c}-0.030 \\
(0.018)\end{array}$ & $\begin{array}{c}0.022 \\
(0.037)\end{array}$ & $\begin{array}{l}-0.017 \\
(0.015)\end{array}$ & $\begin{array}{c}-0.044 \\
(0.021)\end{array}$ & $\begin{array}{l}-0.020 \\
(0.019)\end{array}$ \\
\hline HCBS \$ Allowable & $\begin{array}{l}-0.041 \\
(0.067)\end{array}$ & $\begin{array}{c}-0.006 \\
(0.040)\end{array}$ & $\begin{array}{c}0.031 \\
(0.071)\end{array}$ & $\begin{array}{c}0.085 \\
(0.068)\end{array}$ & $\begin{array}{l}-0.079 \\
(0.074)\end{array}$ & $\begin{array}{c}0.122 \\
(0.078)\end{array}$ \\
\hline $\ln ($ HCBS \$ Loss) & $\begin{array}{c}0.008 \\
(0.021)\end{array}$ & $\begin{array}{c}-0.014 \\
(0.010)\end{array}$ & $\begin{array}{l}-0.048 \\
(0.025)\end{array}$ & $\begin{array}{c}0.008 \\
(0.016)\end{array}$ & $\begin{array}{c}0.040 \\
(0.023)\end{array}$ & $\begin{array}{c}0.006 \\
(0.020)\end{array}$ \\
\hline (Beds/1000 Elderly)/10 & $\begin{array}{c}0.034 \\
(0.022)\end{array}$ & $\begin{array}{c}0.140 \\
(0.014)\end{array}$ & $\begin{array}{c}0.198 \\
(0.025)\end{array}$ & $\begin{array}{l}-0.008 \\
(0.021)\end{array}$ & $\begin{array}{l}-0.013 \\
(0.029)\end{array}$ & $\begin{array}{c}0.046 \\
(0.023)\end{array}$ \\
\hline NH Revenue Loss/10000 & $\begin{array}{l}-0.066 \\
(0.023)\end{array}$ & $\begin{array}{c}-0.008 \\
(0.015)\end{array}$ & $\begin{array}{l}-0.030 \\
(0.031)\end{array}$ & $\begin{array}{c}0.006 \\
(0.024)\end{array}$ & $\begin{array}{c}-0.012 \\
(0.032)\end{array}$ & $\begin{array}{l}-0.011 \\
(0.026)\end{array}$ \\
\hline $\mathrm{HH}+$ Personal \$ / NH \$ & $\begin{array}{c}0.037 \\
(0.027)\end{array}$ & $\begin{array}{c}0.045 \\
(0.018)\end{array}$ & $\begin{array}{l}-0.012 \\
(0.037)\end{array}$ & $\begin{array}{l}-0.038 \\
(0.028)\end{array}$ & $\begin{array}{c}0.152 \\
(0.036)\end{array}$ & $\begin{array}{c}0.013 \\
(0.032)\end{array}$ \\
\hline HCBS \$ / Elig. Elderly / 1000 & $\begin{array}{c}0.064 \\
(0.028)\end{array}$ & $\begin{array}{c}0.008 \\
(0.018)\end{array}$ & $\begin{array}{l}-0.022 \\
(0.035)\end{array}$ & $\begin{array}{l}-0.015 \\
(0.031)\end{array}$ & $\begin{array}{c}0.008 \\
(0.038)\end{array}$ & $\begin{array}{c}0.025 \\
(0.030)\end{array}$ \\
\hline Medicare \$ Change & $\begin{array}{c}0.102 \\
(0.068)\end{array}$ & $\begin{array}{c}-0.022 \\
(0.044)\end{array}$ & $\begin{array}{c}0.034 \\
(0.079)\end{array}$ & $\begin{array}{l}-0.187 \\
(0.066)\end{array}$ & $\begin{array}{r}-0.044 \\
(0.082)\end{array}$ & $\begin{array}{c}0.046 \\
(0.071)\end{array}$ \\
\hline Lag Private Ins. No LTC & $\begin{array}{l}-0.899 \\
(0.083)\end{array}$ & $\begin{array}{c}1.910 \\
(0.046)\end{array}$ & $\begin{array}{c}1.309 \\
(0.121)\end{array}$ & & & \\
\hline Lag Private Ins. with LTC & $\begin{array}{l}-1.435 \\
(0.209)\end{array}$ & $\begin{array}{c}1.489 \\
(0.082)\end{array}$ & $\begin{array}{c}3.807 \\
(0.130)\end{array}$ & & & \\
\hline Lag Medicaid & $\begin{array}{c}2.534 \\
(0.089)\end{array}$ & $\begin{array}{c}0.300 \\
(0.112)\end{array}$ & $\begin{array}{c}0.952 \\
(0.272)\end{array}$ & & & \\
\hline Lag Health & $\begin{array}{c}0.234 \\
(0.019)\end{array}$ & $\begin{array}{c}0.045 \\
(0.014)\end{array}$ & $\begin{array}{c}0.014 \\
(0.028)\end{array}$ & & & \\
\hline Lag Assets & $\begin{array}{l}-0.391 \\
(0.240)\end{array}$ & $\begin{array}{c}0.423 \\
(0.258)\end{array}$ & $\begin{array}{l}-1.396 \\
(0.951)\end{array}$ & $\begin{array}{l}-0.388 \\
(0.275)\end{array}$ & $\begin{array}{r}-0.181 \\
(0.335)\end{array}$ & $\begin{array}{l}-0.631 \\
(0.312)\end{array}$ \\
\hline Lag Assets Squared & $\begin{array}{c}0.031 \\
(0.109)\end{array}$ & $\begin{array}{c}-0.165 \\
(0.122)\end{array}$ & $\begin{array}{c}0.776 \\
(0.468)\end{array}$ & $\begin{array}{c}0.179 \\
(0.129)\end{array}$ & $\begin{array}{c}0.105 \\
(0.157)\end{array}$ & $\begin{array}{c}0.327 \\
(0.147)\end{array}$ \\
\hline Medicaid Eligibility & & $\begin{array}{c}-0.291 \\
(0.156)\end{array}$ & $\begin{array}{l}-0.389 \\
(0.321)\end{array}$ & & & \\
\hline Private Ins. No LTC & & & & $\begin{array}{l}-0.035 \\
(0.071)\end{array}$ & $\begin{array}{c}0.135 \\
(0.104)\end{array}$ & $\begin{array}{l}-0.071 \\
(0.089)\end{array}$ \\
\hline Private Ins. With LTC & & & & $\begin{array}{l}-0.068 \\
(0.146)\end{array}$ & $\begin{array}{l}-0.276 \\
(0.233)\end{array}$ & $\begin{array}{c}0.352 \\
(0.164)\end{array}$ \\
\hline Medicaid & & & & $\begin{array}{c}0.079 \\
(0.101)\end{array}$ & $\begin{array}{c}1.026 \\
(0.133)\end{array}$ & $\begin{array}{c}1.395 \\
(0.118)\end{array}$ \\
\hline Health & & & & $\begin{array}{c}1.196 \\
(0.025)\end{array}$ & $\begin{array}{c}1.622 \\
(0.037)\end{array}$ & $\begin{array}{c}1.247 \\
(0.031)\end{array}$ \\
\hline Health * Health Improved & & & & $\begin{array}{c}0.405 \\
(0.056)\end{array}$ & $\begin{array}{c}0.350 \\
(0.082)\end{array}$ & $\begin{array}{c}0.481 \\
(0.064)\end{array}$ \\
\hline Health * Health Declined a little & & & & $\begin{array}{c}0.039 \\
(0.031)\end{array}$ & $\begin{array}{l}-0.024 \\
(0.037)\end{array}$ & $\begin{array}{l}-0.002 \\
(0.035)\end{array}$ \\
\hline Health * Health Declined a lot & & & & $\begin{array}{l}-0.096 \\
(0.023)\end{array}$ & $\begin{array}{r}-0.168 \\
\quad(0.029)\end{array}$ & $\begin{array}{l}-0.153 \\
(0.027)\end{array}$ \\
\hline
\end{tabular}


Table 3b. Selected Parameter Estimates from the Equation System with Heterogeneity Outcomes: Probability of Any Assets and Gifts, Continuous Assets and Gifts if any

\begin{tabular}{|c|c|c|c|c|}
\hline Explanatory Variables & $\begin{array}{c}\text { Any } \\
\text { Assets } \\
\end{array}$ & $\begin{array}{l}\text { Any } \\
\text { Gifts }\end{array}$ & $\begin{array}{c}\text { Ln(Assets) } \\
\text { If any } \\
\end{array}$ & $\begin{array}{c}\text { Ln(Gifts) } \\
\text { If any } \\
\end{array}$ \\
\hline NH Generosity/10000 & $\begin{array}{c}0.079 \\
(0.030)\end{array}$ & $\begin{array}{l}-0.001 \\
(0.026)\end{array}$ & $\begin{array}{c}0.043 \\
(0.011)\end{array}$ & $\begin{array}{l}-0.006 \\
(0.013)\end{array}$ \\
\hline $\ln (\mathrm{NH} \$$ Loss $)$ & $\begin{array}{c}0.026 \\
(0.019)\end{array}$ & $\begin{array}{c}-0.025 \\
(0.012)\end{array}$ & $\begin{array}{c}0.021 \\
(0.006)\end{array}$ & $\begin{array}{l}-0.011 \\
(0.007)\end{array}$ \\
\hline HCBS \$ Allowable & $\begin{array}{c}0.113 \\
(0.059)\end{array}$ & $\begin{array}{c}0.242 \\
(0.060)\end{array}$ & $\begin{array}{l}-0.069 \\
(0.025)\end{array}$ & $\begin{array}{c}0.010 \\
(0.028)\end{array}$ \\
\hline $\ln$ (HCBS \$ Loss) & $\begin{array}{l}-0.026 \\
(0.020)\end{array}$ & $\begin{array}{c}0.026 \\
(0.012)\end{array}$ & $\begin{array}{l}-0.029 \\
(0.006)\end{array}$ & $\begin{array}{c}0.001 \\
(0.008)\end{array}$ \\
\hline (Beds/1000 Elderly)/10 & $\begin{array}{l}-0.028 \\
(0.023)\end{array}$ & $\begin{array}{c}0.126 \\
(0.016)\end{array}$ & $\begin{array}{l}-0.013 \\
(0.009)\end{array}$ & $\begin{array}{l}-0.010 \\
(0.010)\end{array}$ \\
\hline NH Revenue Loss/10000 & $\begin{array}{c}0.007 \\
(0.025)\end{array}$ & $\begin{array}{l}-0.170 \\
(0.023)\end{array}$ & $\begin{array}{l}-0.062 \\
(0.010)\end{array}$ & $\begin{array}{l}-0.021 \\
(0.012)\end{array}$ \\
\hline $\mathrm{HH}+$ Personal \$ / NH \$ & $\begin{array}{l}-0.062 \\
(0.028)\end{array}$ & $\begin{array}{c}0.023 \\
(0.024)\end{array}$ & $\begin{array}{l}-0.057 \\
(0.012)\end{array}$ & $\begin{array}{l}-0.027 \\
(0.014)\end{array}$ \\
\hline HCBS \$ / Elig. Elderly / 1000 & $\begin{array}{c}0.006 \\
(0.032)\end{array}$ & $\begin{array}{c}-0.001 \\
(0.025)\end{array}$ & $\begin{array}{l}-0.010 \\
(0.012)\end{array}$ & $\begin{array}{l}-0.004 \\
(0.014)\end{array}$ \\
\hline Medicare \$ Change & $\begin{array}{c}0.054 \\
(0.061)\end{array}$ & $\begin{array}{l}-0.279 \\
(0.054)\end{array}$ & $\begin{array}{c}0.005 \\
(0.025)\end{array}$ & $\begin{array}{c}0.010 \\
(0.028)\end{array}$ \\
\hline Private Ins. No LTC & $\begin{array}{c}0.468 \\
(0.076)\end{array}$ & $\begin{array}{c}0.466 \\
(0.074)\end{array}$ & $\begin{array}{c}0.174 \\
(0.028)\end{array}$ & $\begin{array}{c}0.095 \\
(0.035)\end{array}$ \\
\hline Private Ins. With LTC & $\begin{array}{c}0.602 \\
(0.183)\end{array}$ & $\begin{array}{c}0.994 \\
(0.147)\end{array}$ & $\begin{array}{c}0.293 \\
(0.048)\end{array}$ & $\begin{array}{c}0.133 \\
(0.057)\end{array}$ \\
\hline Medicaid & $\begin{array}{c}-0.761 \\
(0.091)\end{array}$ & $\begin{array}{c}-1.367 \\
(0.133)\end{array}$ & $\begin{array}{l}-0.809 \\
(0.049)\end{array}$ & $\begin{array}{c}0.083 \\
(0.073)\end{array}$ \\
\hline Health & $\begin{array}{l}-0.186 \\
(0.022)\end{array}$ & $\begin{array}{l}-0.170 \\
(0.024)\end{array}$ & $\begin{array}{l}-0.037 \\
(0.010)\end{array}$ & $\begin{array}{c}0.059 \\
(0.013)\end{array}$ \\
\hline Lag Assets & $\begin{array}{c}0.988 \\
(0.223)\end{array}$ & $\begin{array}{c}0.990 \\
(0.291)\end{array}$ & $\begin{array}{c}1.564 \\
(0.125)\end{array}$ & $\begin{array}{c}0.524 \\
(0.196)\end{array}$ \\
\hline Lag Assets Squared & $\begin{array}{c}-0.330 \\
(0.102)\end{array}$ & $\begin{array}{c}-0.397 \\
(0.139)\end{array}$ & $\begin{array}{l}-0.491 \\
(0.060)\end{array}$ & $\begin{array}{l}-0.226 \\
(0.095)\end{array}$ \\
\hline Health * Health Improved & $\begin{array}{l}-0.198 \\
(0.058)\end{array}$ & $\begin{array}{l}-0.205 \\
(0.070)\end{array}$ & $\begin{array}{l}-0.080 \\
(0.034)\end{array}$ & $\begin{array}{c}0.012 \\
(0.045)\end{array}$ \\
\hline Health * Health Declined a little & $\begin{array}{l}-0.028 \\
(0.033)\end{array}$ & $\begin{array}{c}0.032 \\
(0.029)\end{array}$ & $\begin{array}{c}0.054 \\
(0.018)\end{array}$ & $\begin{array}{l}-0.012 \\
(0.022)\end{array}$ \\
\hline Health * Health Declined a lot & $\begin{array}{c}0.004 \\
(0.030)\end{array}$ & $\begin{array}{c}0.050 \\
(0.026)\end{array}$ & $\begin{array}{c}0.043 \\
(0.015)\end{array}$ & $\begin{array}{l}-0.001 \\
(0.016)\end{array}$ \\
\hline
\end{tabular}


Table 3c. Selected Parameter Estimates from the Equation System with Heterogeneity Outcomes: Continuous Health Index and Probability of Death

\begin{tabular}{|c|c|c|}
\hline Explanatory Variables & Level of Health & Prob. Of Death \\
\hline Lag Private Ins. No LTC & $\begin{array}{l}-0.048 \\
(0.025)\end{array}$ & \\
\hline Lag Private Ins. With LTC & $\begin{array}{l}-0.113 \\
(0.038)\end{array}$ & \\
\hline Lag Medicaid & $\begin{array}{c}0.121 \\
(0.037)\end{array}$ & \\
\hline Lag Health & $\begin{array}{c}0.484 \\
(0.009)\end{array}$ & \\
\hline Lag Informal Home Care & $\begin{array}{l}-0.057 \\
(0.075)\end{array}$ & \\
\hline Lag Formal Home Care & $\begin{array}{c}0.282 \\
(0.214)\end{array}$ & \\
\hline Lag Nursing Home Care & $\begin{array}{c}0.653 \\
(0.129)\end{array}$ & \\
\hline Lag Health * Lag Informal Care & $\begin{array}{c}0.126 \\
(0.024)\end{array}$ & \\
\hline Lag Health $*$ Lag Formal Care & $\begin{array}{c}0.123 \\
(0.056)\end{array}$ & \\
\hline Lag Health * Lag NH Care & $\begin{array}{c}0.040 \\
(0.036)\end{array}$ & \\
\hline Private Ins. No LTC & & $\begin{array}{c}0.154 \\
(0.073)\end{array}$ \\
\hline Private Ins. With LTC & & $\begin{array}{c}0.167 \\
(0.135)\end{array}$ \\
\hline Medicaid & & $\begin{array}{c}0.053 \\
(0.100)\end{array}$ \\
\hline Health & & $\begin{array}{c}0.141 \\
(0.036)\end{array}$ \\
\hline Informal Home Care & & $\begin{array}{c}3.770 \\
(0.189)\end{array}$ \\
\hline Formal Home Care & & $\begin{array}{c}3.617 \\
(0.328)\end{array}$ \\
\hline Nursing Home & & $\begin{array}{c}2.498 \\
(0.155)\end{array}$ \\
\hline Health * Informal Care & & $\begin{array}{l}-0.736 \\
(0.067)\end{array}$ \\
\hline Health * Formal Care & & $\begin{array}{l}-0.473 \\
(0.093)\end{array}$ \\
\hline Health * NH Care & & $\begin{array}{l}-0.114 \\
(0.053)\end{array}$ \\
\hline Health $*$ Health Improved & & $\begin{array}{c}0.771 \\
(0.053)\end{array}$ \\
\hline Health * Health Declined a little & & $\begin{array}{c}0.051 \\
(0.028)\end{array}$ \\
\hline Health * Health Declined a lot & & $\begin{array}{l}-0.042 \\
(0.026)\end{array}$ \\
\hline
\end{tabular}


Table 4. Observed Data and Model Predictions by Year and by Unobserved Heterogeneity Mass Point

\begin{tabular}{|c|c|c|c|c|c|c|c|c|c|c|c|c|c|c|}
\hline \multirow[t]{2}{*}{ Year } & \multirow{2}{*}{$\begin{array}{c}\text { Medicaid } \\
\text { Yes }\end{array}$} & \multicolumn{3}{|c|}{$\begin{array}{l}\text { Supplemental } \\
\text { Insurance }\end{array}$} & \multirow[t]{2}{*}{ Health } & \multicolumn{4}{|c|}{ Long-Term Care } & \multirow{2}{*}{$\begin{array}{c}\text { Positive } \\
\text { Assets } \\
\text { Yes }\end{array}$} & \multirow{2}{*}{$\begin{array}{c}\begin{array}{c}\text { Assets, } \\
\text { if any }\end{array} \\
\text { (Log) } \\
\end{array}$} & \multirow{2}{*}{$\begin{array}{c}\begin{array}{c}\text { Positive } \\
\text { Gifts }\end{array} \\
\text { Yes } \\
\end{array}$} & \multirow{2}{*}{$\begin{array}{l}\text { Gifts, } \\
\text { if any } \\
\text { (Log) }\end{array}$} & \multirow{2}{*}{$\begin{array}{c}\text { Decease } \\
\text { Yes }\end{array}$} \\
\hline & & None & PN & PY & & None & IC & FC & Yes & & & & & \\
\hline \multicolumn{15}{|l|}{1995} \\
\hline Observed & 12.0 & 24.7 & 55.8 & 7.5 & 1.21 & 77.4 & 13.1 & 3.9 & 5.6 & 85.3 & 9.16 & 48.4 & 3.74 & 10.2 \\
\hline Simulated $^{1}$ & 11.9 & 25.1 & 55.5 & 7.5 & 1.21 & 77.4 & 13.1 & 3.9 & 5.6 & 85.3 & 9.15 & 47.9 & 3.70 & 10.1 \\
\hline Simulated $^{2}$ & 11.9 & 25.1 & 55.5 & 7.5 & 1.21 & 76.7 & 13.5 & 3.8 & 6.0 & 84.9 & 9.08 & 47.0 & 3.64 & 14.4 \\
\hline \multicolumn{15}{|l|}{ Permanent } \\
\hline Mass Point 1 & 9.2 & 20.7 & 60.9 & 9.2 & 0.94 & 79.1 & 14.9 & 4.9 & 1.1 & 94.1 & 11.47 & 99.9 & 10.97 & 8.3 \\
\hline Mass Point 2 & 11.5 & 23.9 & 56.5 & 8.1 & 1.10 & 78.6 & 13.4 & 4.2 & 3.7 & 89.0 & 9.93 & 84.4 & 7.30 & 9.4 \\
\hline Mass Point 3 & 11.7 & 24.8 & 55.7 & 7.7 & 1.19 & 77.7 & 13.2 & 4.0 & 5.2 & 86.2 & 9.30 & 55.6 & 4.22 & 10.0 \\
\hline Mass Point 4 & 12.3 & 26.2 & 54.5 & 7.0 & 1.29 & 76.3 & 12.8 & 3.6 & 7.3 & 82.2 & 8.52 & 17.4 & 1.13 & 10.6 \\
\hline \multicolumn{15}{|l|}{ Time-Varying } \\
\hline Mass Point 1 & 13.7 & 23.7 & 55.5 & 7.0 & 1.28 & 80.2 & 12.4 & 3.2 & 4.2 & 90.9 & 9.69 & 61.8 & 4.50 & 6.4 \\
\hline Mass Point 2 & 8.6 & 27.5 & 55.4 & 8.4 & 1.08 & 72.4 & 14.4 & 5.1 & 8.0 & 75.5 & 8.20 & 23.1 & 2.26 & 16.7 \\
\hline \multicolumn{15}{|l|}{1998} \\
\hline Observed & 12.8 & 29.2 & 51.1 & 7.0 & 1.45 & 69.1 & 12.5 & 6.9 & 11.5 & 85.8 & 9.31 & 47.4 & 3.84 & 13.6 \\
\hline Simulated $^{1}$ & 12.8 & 29.1 & 51.1 & 7.0 & 1.45 & 69.0 & 12.6 & 7.1 & 11.4 & 86.2 & 9.32 & 46.7 & 3.75 & 13.4 \\
\hline Simulated $^{2}$ & 12.7 & 28.4 & 48.8 & 10.1 & 1.35 & 70.7 & 11.5 & 5.9 & 11.8 & 81.9 & 8.88 & 43.7 & 3.52 & 14.9 \\
\hline \multicolumn{15}{|l|}{ Permanent } \\
\hline Mass Point 1 & 11.6 & 25.8 & 53.8 & 8.8 & 1.20 & 71.9 & 15.8 & 8.9 & 3.4 & 94.8 & 11.54 & 99.9 & 11.20 & 10.9 \\
\hline Mass Point 2 & 12.1 & 28.2 & 52.0 & 7.7 & 1.34 & 71.0 & 13.4 & 7.7 & 7.9 & 89.6 & 10.07 & 83.2 & 7.45 & 12.5 \\
\hline Mass Point 3 & 12.7 & 28.8 & 51.4 & 7.1 & 1.43 & 69.3 & 12.8 & 7.2 & 10.6 & 86.9 & 9.45 & 54.1 & 4.27 & 13.3 \\
\hline Mass Point 4 & 13.3 & 30.2 & 50.1 & 6.5 & 1.53 & 67.4 & 11.7 & 6.6 & 14.2 & 83.2 & 8.72 & 16.8 & 1.14 & 14.0 \\
\hline \multicolumn{15}{|l|}{ Time-Varying } \\
\hline Mass Point 1 & 14.7 & 27.7 & 51.1 & 6.5 & 1.52 & 72.2 & 12.4 & 6.3 & 9.1 & 91.3 & 9.81 & 60.4 & 4.58 & 8.9 \\
\hline Mass Point 2 & 9.3 & 31.8 & 51.1 & 7.8 & 1.31 & 63.3 & 12.9 & 8.6 & 15.3 & 77.1 & 8.46 & 22.6 & 2.27 & 21.3 \\
\hline
\end{tabular}


Table 4. Observed Data and Model Predictions by Year and by Unobserved Heterogeneity Mass Point -- continued

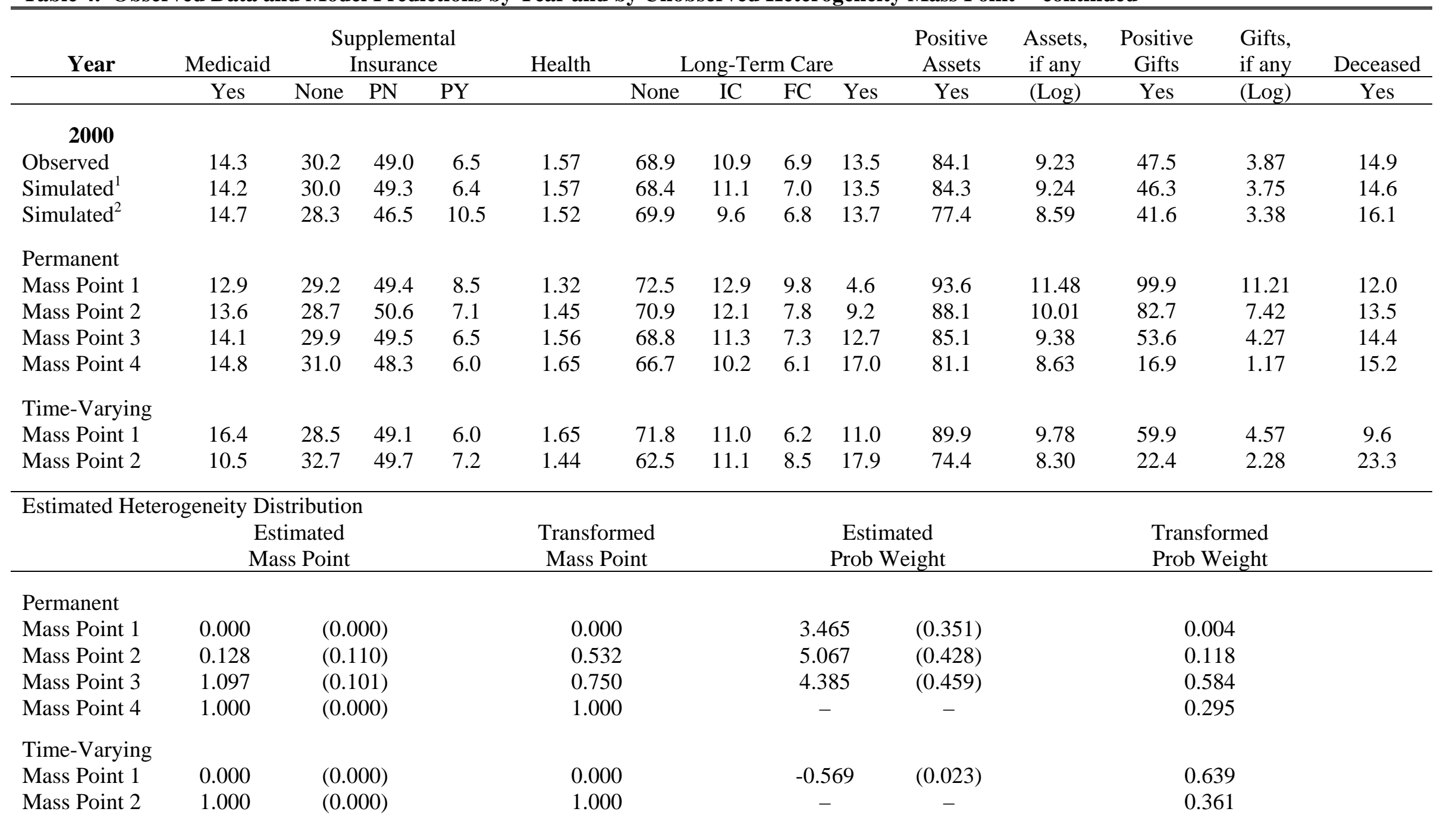

${ }^{1}$ Simulated outcomes are based on the model estimates, random error draws, and observed values of all explanatory variables.

${ }^{2}$ Simulated outcomes are based on the model estimates, random error draws, and updated values of the endogenous explanatory variables. 
Table 5a. Baseline Simulated Outcomes categorized by 1993 observed marital status and asset level

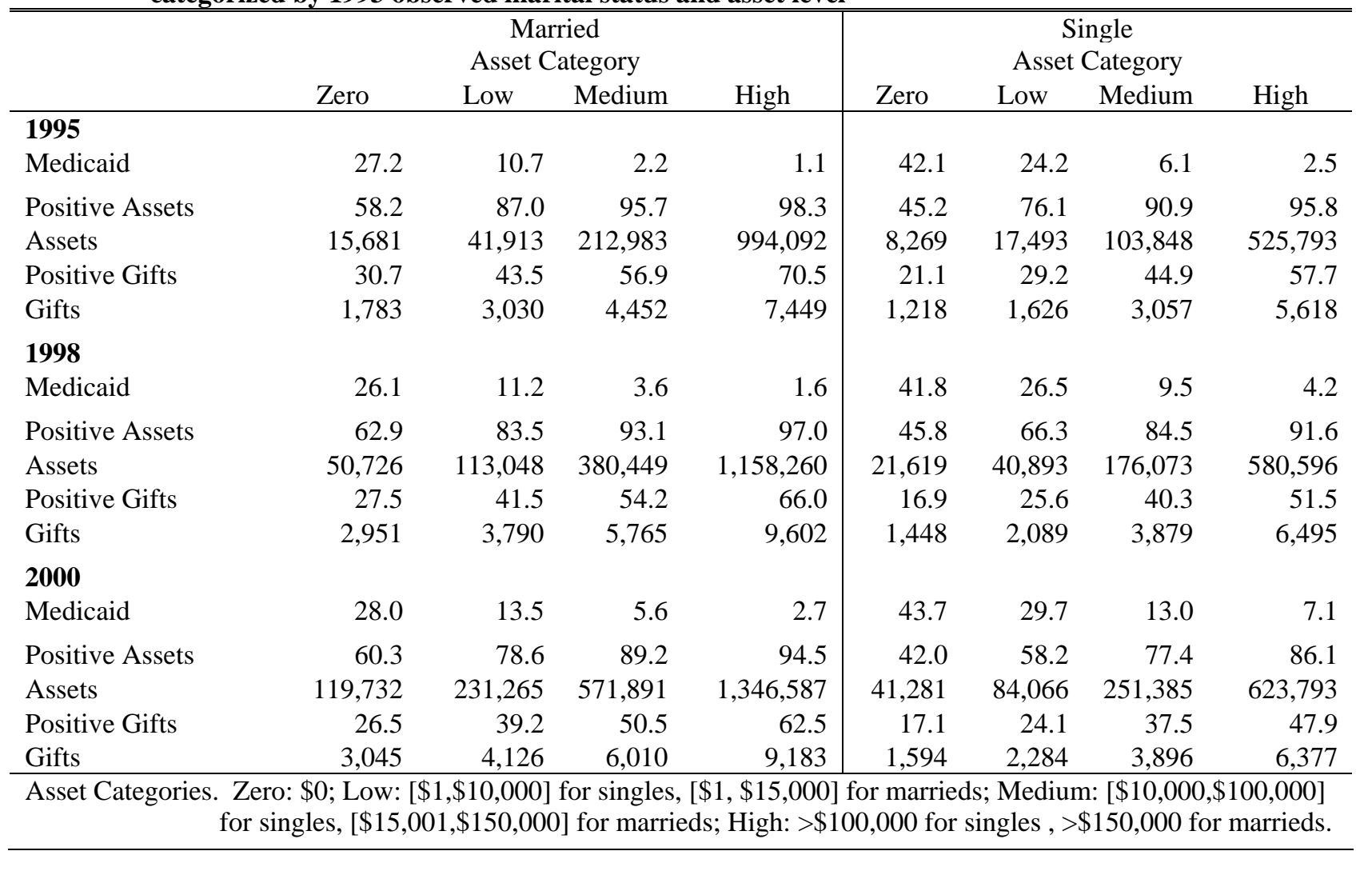

Table 5b. Policy Simulation 1: Asset limits for nursing home eligibility are doubled categorized by 1993 observed marital status and asset level

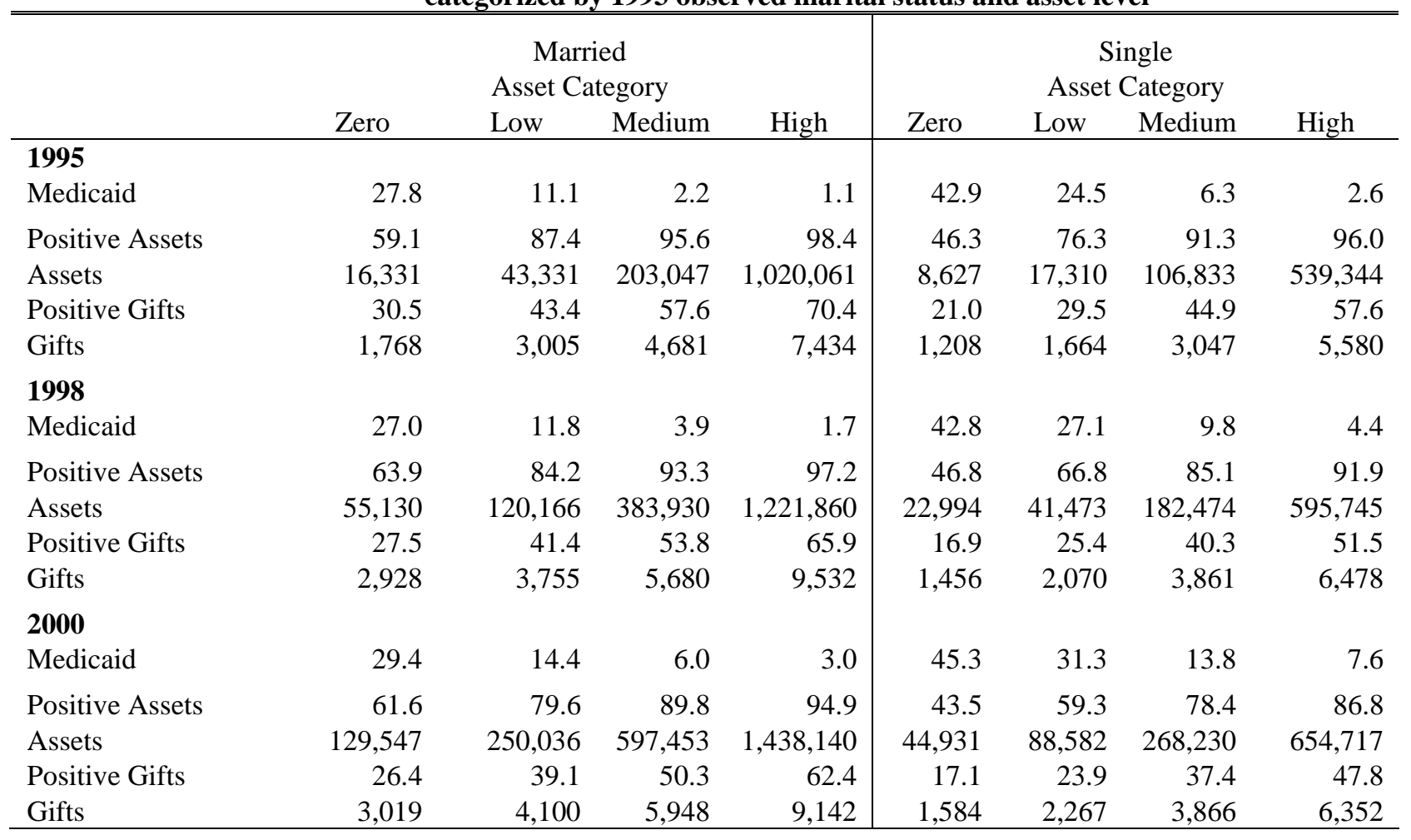


Table 5c. Policy Simulation 2: Asset limits for paid home care eligibility are doubled categorized by 1993 observed marital status and asset level

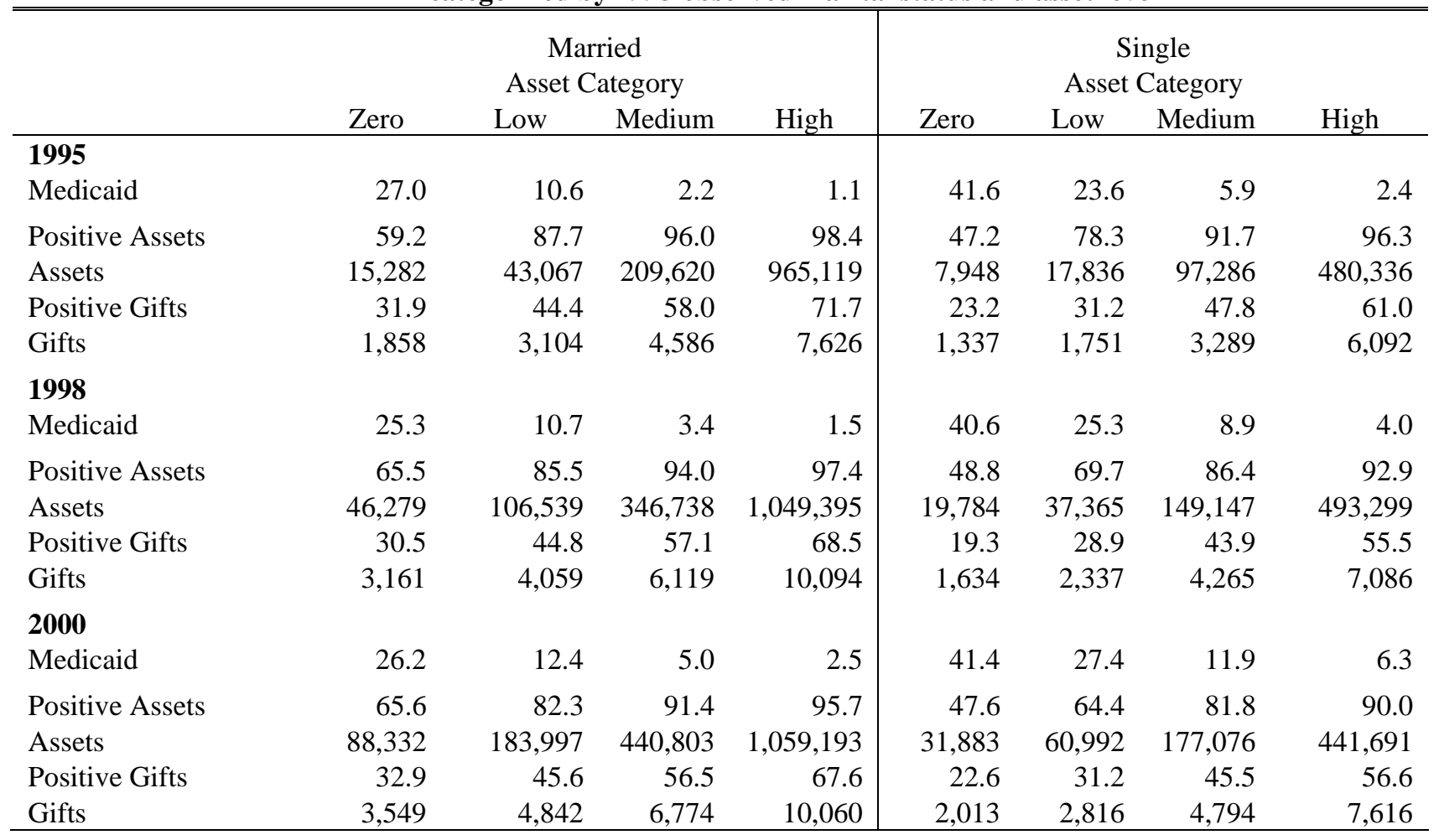

Table 5d. Policy Simulation 3: Long-Term Care Spending Ratio Increased 50 Percent categorized by 1993 observed marital status and asset level

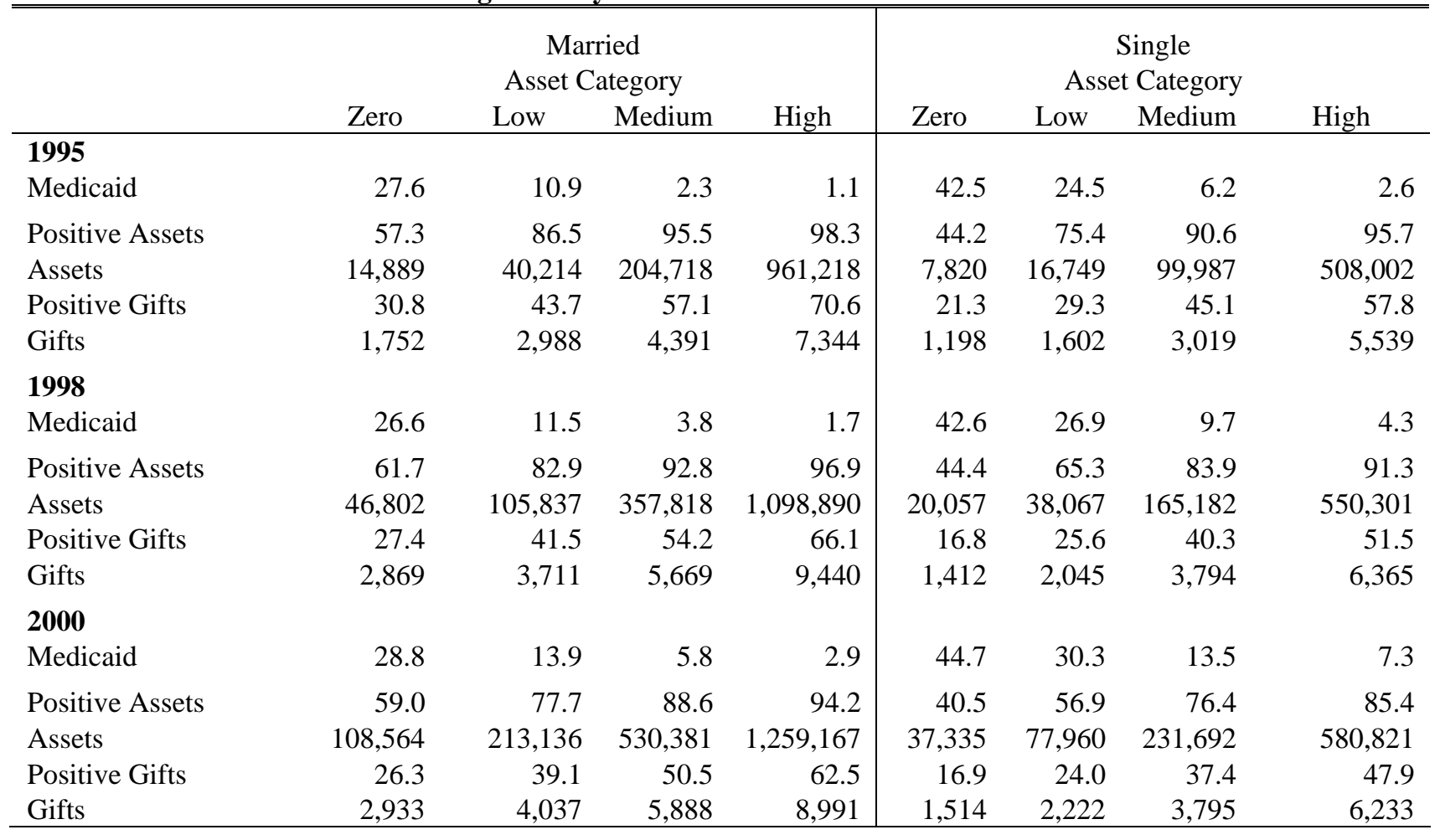




\section{APPENDIX A}

\section{Identification}

Identification in a system of dynamic equations such as this appears difficult to assess at first glance. However, most of the model is identified using the structure of the equations imposed by the theoretical model. For example, lagged values of endogenous outcomes enter almost all equations in the system (except the initial conditions, which will be discussed separately below). These lagged values serve as exclusion restrictions, but also contain other lagged values and additional lags by construction. Hence there is a great deal of variation in these lags and their determinants that serve to identify the model.

Because the initial conditions do not contain lagged values (due to lack of data), separate variables that represent sources of exogenous variation must be included. These variables should be significant in the initial equations, but, conditional on the lagged values of the state variables, the variables used as exclusions in the initial equations should not be significant in the period $t>0$ equations. ${ }^{33}$ The coefficients on the exclusion restrictions were significantly different from zero and the variables, in most cases, were not significant in the main equations of the model. Additionally, the model is identified by the nonlinearities in the functional form of included variables and the covariance restrictions on the error terms.

In the first period of data used in this analysis, no institutionalized persons are interviewed. Although the initial conditions are estimated jointly with the structural equations in the empirical model, theoretically the fact that there are no institutionalized persons sampled in the first period could bias estimates because of selection. However, the average stay in a nursing home is quite short. Of the 384 persons who entered a nursing home between 1993 and 1995, 41\% had deceased by 1995 and 89\% had deceased by 2000 .

\footnotetext{
${ }^{33}$ Variables used for identification of the initial conditions are in Table A4 of Appendix A. Coefficient estimates are available upon request.
} 
Table A1. Medicaid Eligibility Limits for the Aged by State, 1998

\begin{tabular}{|c|c|c|c|c|c|c|}
\hline \multirow[b]{2}{*}{ State } & \multicolumn{3}{|c|}{ Categorically Needy } & \multicolumn{2}{|c|}{ Medically Needy } & Asset Limits \\
\hline & HCBS & $\mathrm{NH}$ & & HCBS & $\mathrm{NH}$ & \\
\hline Alabama & 494 & 1,482 & 2,000 & --- & --- & --- \\
\hline Arizona & 1,482 & 1,482 & 2,000 & --- & --- & --- \\
\hline Arkansas & 1,482 & 1,482 & 2,000 & 108 & --- & 2,000 \\
\hline California & 650 & 650 & 2,000 & 600 & 600 & 2,000 \\
\hline Colorado & 1,482 & 1,482 & 2,000 & --- & --- & --- \\
\hline Connecticut $^{\mathrm{b}}$ & 1,482 & 1,482 & 1,600 & 476 & 476 & 1,600 \\
\hline District of Columbia & --- & 512 & 2,000 & 377 & 377 & 2,600 \\
\hline Florida & 1,482 & 1,482 & 5,000 & 180 & N/A & 5,000 \\
\hline Georgia & 1,482 & 1,482 & 2,000 & 317 & 317 & 2,000 \\
\hline Idaho & 1,482 & 1,482 & 2,000 & --- & --- & --- \\
\hline Illinois $^{\mathrm{b}}$ & 554 & 283 & 2,000 & 283 & 283 & 2,000 \\
\hline Indiana $^{\mathrm{b}}$ & 494 & 494 & 1,500 & 494 & 494 & 1,500 \\
\hline Iowa & 1,482 & 1,482 & 2,000 & 483 & N/A & 10,000 \\
\hline Kansas & 1,482 & 1,482 & 2,000 & 475 & 475 & 2,000 \\
\hline Louisiana & 1,482 & 1,482 & 2,000 & N/A & 100 & 2,000 \\
\hline Maryland & 988 & 1,482 & 2,000 & 350 & 350 & 2,500 \\
\hline Massachusetts & 651 & 623 & 2,000 & 651 & 651 & 2,000 \\
\hline Michigan & 1,482 & 1,482 & 2,000 & 408 & 408 & 2,000 \\
\hline Minnesota $^{\mathrm{b}}$ & 1,482 & 1,482 & 3,000 & 467 & 467 & 3,000 \\
\hline Missouri $^{\mathrm{b}}$ & 932 & 932 & 999.99 & 494 & 821 & 999.99 \\
\hline Nebraska & 651 & 502 & 4,000 & 392 & 392 & 4,000 \\
\hline New Hampshire ${ }^{\mathrm{b}, \mathrm{c}}$ & 1,165 & 1,165 & 1,500 & 508 & 508 & 2,500 \\
\hline New Jersey ${ }^{c}$ & 1,482 & 1,482 & 2,000 & 367 & --- & 4,000 \\
\hline New Mexico & 1,270 & 1,270 & 2,000 & --- & --- & --- \\
\hline New York & 580 & 580 & 2,000 & 584 & 584 & 3,500 \\
\hline North Carolina & 651 & 494 & 2,000 & 242 & 242 & 1,500 \\
\hline Ohio $^{\mathrm{b}}$ & 427 & 1,281 & 1,500 & 427 & 427 & 1,500 \\
\hline Oregon & 1,482 & 1,482 & 2,000 & N/A & N/A & 5,000 \\
\hline Pennsylvania $^{c}$ & 1,482 & 1,482 & 2,400 & 425 & 425 & 2,400 \\
\hline South Carolina & 1,482 & 1,482 & 2,000 & --- & --- & --- \\
\hline Tennessee & 1,482 & 1,482 & 2,000 & 175 & 175 & 2,000 \\
\hline Texas & 1,482 & 1,482 & 2,000 & N/A & N/A & N/A \\
\hline Virginia $^{\mathrm{b}}$ & 1,482 & 1,482 & 2,000 & 250 & 250 & 2,000 \\
\hline Washington & 1,482 & 1,482 & 2,000 & 521 & 521 & 2,000 \\
\hline West Virginia & 1,482 & 1,482 & 2,000 & 200 & 200 & 2,000 \\
\hline Wisconsin & 1,482 & 1,482 & 2,000 & 578 & 578 & 2,000 \\
\hline Wyoming & 1,482 & 1,482 & 2,000 & --- & --- & --- \\
\hline
\end{tabular}

Sources: NASMD; Bruen et al., correspondence with state Medicaid offices; Kassner et al., 2000.

Note: The 1998 federal poverty level (FPL) is $\$ 8,050$ for one person (Source: Federal Register, 1998).

a) Comm = Living in the community with a HCBS Waiver; $\mathrm{NH}=$ Residence in a nursing home.

b) These are 209(b) states. If they do not have a medically needy program they must allow spend down to their categorically needy income limits.

b) Connecticut and Virginia have income limits that vary by region.

c) These states have different asset limits for NH and HCBS eligibility. Ones shown are for NH; for HCBS, the limits are: New Hampshire - \$1,500; New Jersey - \$2,000; and Pennsylvania - \$2,000.

d) Limits with 'N/A' have a medically needy program, but it does not cover the indicated service. 
Table A2. Maintenance Needs Allowances and Spousal Protection Limits

\begin{tabular}{|c|c|c|c|c|c|c|c|}
\hline \multirow[b]{3}{*}{ State } & \multirow{3}{*}{$\begin{array}{l}\text { MNA }^{1} \\
\text { HCBS }\end{array}$} & \multicolumn{6}{|c|}{$\begin{array}{l}\text { Spousal Protection Limits } \\
\text { Assets }\end{array}$} \\
\hline & & \multicolumn{2}{|c|}{ Minimum } & \multicolumn{2}{|c|}{ Maximum } & & \\
\hline & & Nursing & HCBS & Nursing & HCBS & Nursing & HCBS \\
\hline Alabama & 562 & 25,000 & 0 & 25,000 & 0 & 1,295 & 0 \\
\hline Arizona & 1,410 & 15,347 & 15,347 & 76,740 & 76,740 & 1,919 & 1,919 \\
\hline Arkansas & 1,410 & 76,740 & 0 & 76,740 & 0 & 1,919 & 0 \\
\hline California & 600 & 76,740 & 76,740 & 76,740 & 76,740 & 1,919 & 1,919 \\
\hline Colorado & 1,410 & 15,347 & 0 & 76,740 & 0 & 1,919 & 0 \\
\hline Connecticut & 1,254 & 15,347 & 15,347 & 76,740 & 76,740 & 1,919 & 1,919 \\
\hline District of Columbia & 0 & 15,347 & 0 & 15,347 & 0 & 1,919 & 0 \\
\hline Florida & 1,410 & 76,740 & 0 & 76,740 & 0 & 1,919 & 0 \\
\hline Georgia & 470 & 76,740 & 76,740 & 76,740 & 76,740 & 1,919 & 1,919 \\
\hline Idaho & 530 & 15,347 & 15,347 & 76,740 & 76,740 & 1,919 & 1,919 \\
\hline Illinois & 283 & 76,740 & 76,740 & 76,740 & 76,740 & 1,919 & 1,919 \\
\hline Indiana & 470 & 15,347 & 0 & 15,347 & 0 & 1,919 & 0 \\
\hline Iowa & 1,410 & 21,169 & 21,169 & 76,740 & 76,740 & 1,919 & 0 \\
\hline Kansas & 627 & 15,347 & 15,347 & 15,347 & 15,347 & 1,919 & 1,919 \\
\hline Louisiana & 1,410 & 76,740 & 76,740 & 76,740 & 76,740 & 1,919 & 0 \\
\hline Maryland & 350 & 76,740 & 0 & 76,740 & 0 & 1,919 & 0 \\
\hline Massachusetts & 627 & 76,740 & 0 & 76,740 & 0 & 1,919 & 0 \\
\hline Michigan & 1,410 & 76,740 & 76,740 & 76,740 & 76,740 & 1,919 & 1,919 \\
\hline Minnesota & 467 & 24,247 & 24,247 & 24,247 & 24,247 & 1,919 & 1,919 \\
\hline Missouri & 863 & 15,347 & 15,347 & 15,347 & 15,347 & 1,919 & 0 \\
\hline Nebraska & 392 & 15,347 & 15,347 & 15,347 & 15,347 & 1,295 & 1,295 \\
\hline New Hampshire & 508 & 15,347 & 0 & 15,347 & 0 & 1,919 & 0 \\
\hline New Jersey & 1,410 & 15,347 & 15,347 & 76,740 & 76,740 & 1,919 & 1,919 \\
\hline New Mexico & 1,207 & 27,600 & 27,600 & 76,740 & 76,740 & 1,919 & 1,919 \\
\hline New York & 584 & 70,000 & 70,000 & 70,000 & 70,000 & 1,919 & 1,919 \\
\hline North Carolina & 242 & 15,347 & 15,347 & 15,347 & 15,347 & 1,919 & 0 \\
\hline Ohio & 964 & 15,347 & 15,347 & 76,740 & 76,740 & 1,919 & 1,919 \\
\hline Oregon & 476 & 15,347 & 15,347 & 76,740 & 76,740 & 1,295 & 1,295 \\
\hline Pennsylvania & 502 & 15,347 & 0 & 15,347 & 0 & 1,919 & 0 \\
\hline South Carolina & 1,410 & 66,480 & 66,480 & 66,480 & 66,480 & 1,479 & 1,479 \\
\hline Tennessee & 940 & 15,347 & 15,347 & 76,740 & 76,740 & 1,919 & 1,919 \\
\hline Texas & 1,410 & 15,347 & 15,347 & 76,740 & 15,347 & 1,919 & 0 \\
\hline Virginia & 470 & 76,740 & 76,740 & 76,740 & 76,740 & 1,919 & 1,919 \\
\hline Washington & 627 & 76,740 & 76,740 & 76,740 & 76,740 & 1,919 & 1,919 \\
\hline West Virginia & 1,410 & 76,740 & 0 & 76,740 & 0 & 1,919 & 0 \\
\hline Wisconsin & 710 & 44,103 & 44,103 & 76,740 & 76,740 & 1,919 & 1,919 \\
\hline Wyoming & 1,410 & 76,740 & 76,740 & 76,740 & 76,740 & 1,919 & 1,919 \\
\hline
\end{tabular}


Table A3. Supply-Side Policy Variables, 1998

\begin{tabular}{|c|c|c|c|c|c|}
\hline State & $\begin{array}{l}\text { Ratio of Medicaid } \\
\text { Spending: Home to } \\
\text { Institutionalization } \\
\text { (HH+Personal\$/NH\$) }\end{array}$ & $\begin{array}{l}\text { Number of } \\
\text { Beds Per } \\
\text { 1000 Elderly } \\
\text { (Bed/1000 Eld) }\end{array}$ & $\begin{array}{l}\text { Medicaid } \\
\text { Nursing } \\
\text { Home Rate } \\
\text { Per Day }\end{array}$ & $\begin{array}{c}\text { Average HCBS } \\
\text { Spending per } \\
\text { Eligible }^{2} \text { Elderly } \\
\text { per Year } \\
\text { (HCBS\$/Elig. Elderly) }\end{array}$ & $\begin{array}{c}\text { Out-of } \\
\text { Pocket } \\
\text { Nursing Home } \\
\text { Cost Per Day }\end{array}$ \\
\hline Alabama & 4 & 42 & 101.69 & 223.42 & 102.19 \\
\hline Arizona & 8 & 23 & 91.16 & 0 & 130.16 \\
\hline Arkansas & 27 & 64 & 63.03 & 1533.3 & 93.65 \\
\hline California & 20 & 30 & 83.02 & 20.38 & 162.17 \\
\hline Colorado & 15 & 47 & 98.33 & 850.59 & 105.95 \\
\hline Connecticut & 13 & 60 & 128.03 & 997.5 & 230.16 \\
\hline DC & 9 & 30 & 146.15 & 0 & 161.11 \\
\hline Florida & 9 & 27 & 100.28 & 182.16 & 122.75 \\
\hline Georgia & 7 & 50 & 77.61 & 246.88 & 107.54 \\
\hline Idaho & 21 & 42 & 88.72 & 258.5 & 116.69 \\
\hline Illinois & 1 & 69 & 70.15 & 1286.59 & 133.93 \\
\hline Indiana & 7 & 79 & 81.06 & 139.87 & 128.97 \\
\hline Iowa & 14 & 74 & 80.09 & 1615.75 & 92.06 \\
\hline Kansas & 9 & 78 & 70.80 & 9403.77 & 94.44 \\
\hline Louisiana & 4 & 77 & 60.04 & 27.53 & 72.62 \\
\hline Maryland & 14 & 34 & 104.41 & 25.71 & 133.73 \\
\hline Massachusetts & 17 & 58 & 117.97 & 123.15 & 203.97 \\
\hline Michigan & 21 & 37 & 89.50 & 52.4 & 130.16 \\
\hline Minnesota & 18 & 68 & 107.44 & 2991.76 & 145.24 \\
\hline Missouri & 14 & 64 & 90.47 & 2967.16 & 117.06 \\
\hline Nebraska & 7 & 77 & 83.17 & 331.14 & 164.28 \\
\hline New & 3 & 51 & 109.56 & 10409.08 & 149.21 \\
\hline New Jersey & 21 & 39 & 117.36 & 252.55 & 172.22 \\
\hline New Mexico & 3 & 29 & 132.45 & 379.15 & 122.22 \\
\hline New York & 43 & 39 & 157.00 & 38.54 & 182.54 \\
\hline North & 26 & 40 & 97.87 & 733.32 & 115.08 \\
\hline Ohio & 2 & 63 & 109.23 & 494.75 & 152.12 \\
\hline Oregon & 11 & 31 & 84.68 & 2299.54 & 113.89 \\
\hline Pennsylvania & 2 & 48 & 116.38 & 325.23 & 133.35 \\
\hline South & 6 & 35 & 81.76 & 453.08 & 104.36 \\
\hline Tennessee & 0 & 57 & 104.79 & 25.77 & 103.18 \\
\hline Texas & 16 & 56 & 75.38 & 441.84 & 41,425 \\
\hline Virginia & 2 & 33 & 79.08 & 687.84 & 50,405 \\
\hline Washington & 24 & 39 & 114.38 & 1476.12 & 52,722 \\
\hline West Virginia & 19 & 20 & 115.73 & 10591.1 & 47,218 \\
\hline Wisconsin & 15 & 63 & 89.21 & 1179.47 & 49,986 \\
\hline Wyoming & 9 & 57 & 101.25 & 771.59 & 36,500 \\
\hline
\end{tabular}

Sources: Number of Nursing Home Beds: Harrington et al., 2000

Elderly Population: U.S. Census Bureau.

Medicaid Nursing Home Payment Rates: Harrington et al., 1999; Bectel et al., 1998

HCBS Expenditures per Participant: Home and Community Based Services Resource Network

Number of Elderly Enrolled in SSI: Green Book (http://aspe.os.dhhs.gov/98gb/intro.htm)

Total Medicaid Spending on Personal Care, Nursing Home Care, and Mandatory Home Care:

Costs are from the CNN Money calculator at

http://cgi.money.cnn.com/tools/elder_care/elder_care_cost_finder.html

and indexed by a medical services price index from

httD://www.econmagic.com/em-cgi/data.exe/blscu/CUUR0000SAM2.

${ }^{1}$ This is the ratio of total Medicaid spending on the optional Personal Care program and Mandatory Home care to total spending on Nursing Home Care.

${ }^{2}$ These are average HCBS expenditures per eligible elderly, not per elderly participant. An elderly individual is considered eligible if enrolled in Supplemental Securitv Income (SSI). 
Table A4. Exclusion Restrictions for Initial Conditions (1993)

\begin{tabular}{ll}
\hline \hline Dependent Variable & Independent Variables \\
\hline Insurance Choice & Number of Years Worked \\
& Hospitalization in Previous Year Indicator \\
& Spouse's Sex Interacted with Spouse's Education Status \\
& Type of Job Indicators (nine) \\
& Health of the Spouse \\
& Number of grand-children \\
Long-Term Care Choice & Health of the Spouse \\
& Number of Sisters Living \\
& Number of Brothers Living \\
& Mother has 8 or more years of Education Indicator \\
Health & Father has 8 or more years of Education Indicator \\
& Age of Mother at her Death \\
& Age of Father at his Death \\
& Years Worked \\
Assets & Spouse's Sex Interacted with Spouse's Education Status \\
& Type of Job Indicators (nine) \\
& Health of the Spouse \\
\end{tabular}

Table A5. Definition of Selected Endogenous Variables

Private Insurance No LTC Private Insurance With LTC Medicaid

Health

Assets

Gifts

Medicaid Eligibility

Informal Home Care

Formal Home Care

Nursing Home Resident

Health * Health Improved

Health * Health Declined a little

Health * Health Declined a lot

Health * Informal Home Care

Health * Formal Home Care

Health $*$ NH Resident
Indicator $=1$ if had private insurance that does not cover long-term care Indicator $=1$ if had private insurance that does cover long-term care Indicator $=1$ if had Medicaid coverage

Health (health is worse as number increases) Unprotected Assets (Log)

Gifts (Log)

Indicator $=1$ if eligible for Medicaid at the beginning of the period Indicator $=1$ if received unpaid home care at least twice a week Indicator $=1$ if received paid home care at least twice a week Indicator $=1$ if living in a Nursing Home Health * Indicator $=1$ if health improved $\left(\right.$ Health $_{t}-$ Health $\left.\left._{t-1}\right)<0\right)$

Health * Indicator $=1$ if health declined a little $\left(\right.$ Health $_{t}-$ Health $\left.\left._{t-1}\right)<2\right)$

Health * Indicator $=1$ if health declined a lot $\left(\right.$ Health $_{t}-$ Health $\left.\left._{t-1}\right)>=2\right)$

Health * Indicator $=1$ if received informal home care

Health * Indicator $=1$ if received formal home care

Health * Indicator $=1$ if live in nursing home 


\section{REFERENCES}

Bectel, Robert and Natalie Graves, “Across the States 1998: Profiles of Long-Term Care Syste,s,” AARP, Washington D.C. (1998).

Bruen, Brian K., Wiener, Joshua M., Kim, Johnny, and Ossai Miazad, “State Usage of Medicaid Coverage Options for Aged, Blind, and Disabled People,” The Urban Institute (1999).

Currie, Janet and Gruber, Jonathan, "Saving Babies: The Efficacy and Cost of Recent Expansions of Medicaid Eligibility for Pregnant Women.” Journal of Political Economy, 104(6) (1996).

Ettner, Susan L., "Do Elderly Medicaid Patients Experience Reduced Access to Nursing Home Care?”, Journal of Health Economics 12 (1993).

Federal Register, Vol. 63, No. 36, February 24, 1998, pp. 9235-9238

(http://aspe.hhs.gov/poverty/98poverty.htm).

Gertler, P.J., "Medicaid and the Cost of Improving Access to Nursing Home Care, Review of Economics and Statistics 74 (1992).

Greene, V.L., Lovely, M.E. and J.I. Ondrich, “The Cost-Effectiveness of Community Services on a Frail Elderly Poplation,” Gerontologist 33 (1993).

Greene, V. and J.I. Ondrich, "Risk Factors for Nursing Home Admissions and Exits in the National Long Term Care Channeling Demonstration: A Discrete-Time Hazard Function Approach.” Journal of Gerontology: Social Science 45 (1990).

Gruber, Jonathan and Yelowitz, Aaron, "Public Health Insurance and Private Savings," Journal of Political Economy, 107(6) (1999).

Harrington, Charlene, Carrillo, Helen, Thollaug, Susan C., Summers, Peter R., and Valerie Wellin, "Nursing Facilities, Staffing, Residents, and Facility Deficiencies, 1992 Through 1998," San Francisco: Department of Social and Behavioral Sciences, University of California (2000) http://www.hcfa.org/medicaid/nursfac98.pdf

Harrington, Charlene, Swan, James, Wellin, Valerie, Clemeña, Wendy, Carrillo, Helen, and Carrie Griffin, "1997 State Data Book on Long Term Care Program and Market Characteristics,” San Francisco: Department of Social and Behavioral Sciences, University of California (1999).

Heckman, J. and B. Singer, “A Method for Minimizing the Impact of Distributional Assumptions in Econometric Models for Duration Data,” Econometrica 52 (1984). 
Hoerger, Thomas J., Picone, Gabriel A., and Frank A. Sloan, "Public Subsidies, Private Provision of Care and Living Arrangements of the Elderly,” Review of Economics and Statistics 78 (1996).

Hubbard, R. Glenn, Skinner, Jonathan, and Stephen P. Zeldes, “The Importance of Precautionary Motives in Explaining Individual and Aggregate Saving,” CarnegieRochester Conf. Ser. Public Policy 40 (1994).

Hubbard, R. Glenn, Skinner, Jonathan, and Stephen P. Zeldes, "Precautionary Saving and Social Insurance,” Journal of Political Economy 103 (1995).

Kassner, E. and Shirey, L., “Medicaid Financial Eligibility for Older People: State Variations in Access to Home and Community-Based Waiver and Nursing Home Services,” AARP PPI: Washington, D.C. (2000).

Liu, Korbin, Pamela Doty, and Kenneth Manton, "Medicaid Spend-down in Nursing Homes," Gerontologist 30 (1990).

Liu, K., McBride, T.D. and T.A. Coughlin, "Predicting Nursing Home Admissions and Length of Stay: A Duration Analysis,” Medical Care 29(2) (1991).

McKnight, Robin, "Home Care Reimbursement, Long-Term Care Utilization, and Health Outcomes,” Working Paper, http://econ-

www.mit.edu/graduate/candidates.research.htm?athenan=robinmck (2002).

Moses, Stephen A., "The Fallacy of Impoverishment," Gerontologist 30 (1990).

Mroz, Tom, "Discrete Factor Approximation in Simultaneous Equation Models:

Estimating the Impact of a Dummy Endogenous Variable on a Continuous Outcome," Journal of Econometrics 92 (1999).

Mroz, Tom and David Guilkey, "Discrete Factor Approximations for Use in Simultaneous Equations Models with Both Continuous and Discrete Endogenous Variables,” mimeo, Department of Economics, University of North Carolina at Chapel Hill (1992).

National Association of State Medicaid Directors (NASMD), http://www.nasmd.org/.

Norton, Edward, "Elderly Assets, Medicaid Policy, and Spend-Down in Nursing Homes," Review of Income and Wealth 41 (1995).

Norton, Edward, “Long Term Care,” in A.J. Culyer and J.P. Newhouse, eds. Handbook of Health Economics, Elsevier Science (2000).

Sloan, Frank A., and May W. Shayne, "Long-term Care, Medicaid, and Impoverishment of the Elderly," The Milbank Quarterly 71 (1993). 
Sloan, F. A., Hoerger, T.J., and Picone, G., "Pubic Subsidies, Private Provision of Care and Living Arrangements of the Elderly,” The Review of Economics and Statistics 78(3) (1996).

Spence, D., and Wiener, J., "Estimating the Extent of Medicaid Spend-Down in Nursing Homes," Journal of Health Politics, Policy and Law, Vol. 15, No. 3, Fall 1990.

Taylor, D.H., Sloan, F.A., and E.C. Norton, "Formation of Trusts and Spend Down to Medicaid,” Journal of Gerontology: Social Sciences, 54B (1999).

Tilly, Jane, Goldenson, Susan, and Jessica Kasten, “Long-Term Care: Consumers, Providers, and Financing A Chart Book,” Urban Institute (2001).

U.S. General Accounting Office, "Nursing Homes: Admission Problems for Medicaid Recipients and Attempts to Solve them," Washington D.C.: U.S. Government Printing Office, GAO/HRD-90-135, 1990.

Venti, Stephen F. and David A. Wise, “Aging, Moving, and Housing Wealth,” in David A. Wise, ed., The Economics of Aging, Chicago: The University of Chicago Press (1989a).

Venti, Stephen F. and David A. Wise, “But They Don’t Want to Reduce Housing Equity,” NBER Working Paper \#2859 (1989b).

Venti, Stephen F. and David A. Wise, “Aging and the Income Value of Housing Wealth,” Journal of Public Economics, 44 (1991).

Wiener, Joshua M., "Can Medicaid Long-Term Care Expenditures for the Elderly be Reduced?” Gerontologist 36 (6) (1996).

Wiener, Joshua M. Stevenson, David G., and S.M. Goldenson, "Controlling the Supply of Long-Term Care Providers at the State Level,” The Urban Institute, Occasional paper No. 22 (1998). 